\title{
BIPOLE-DIPOLE INTERPRETATION WITH
}

THREE-DIMENSIONAL MODELS

(Including a Field Study of Las Alturas, New Mexico)

by
Gerald W. Hohmann
and

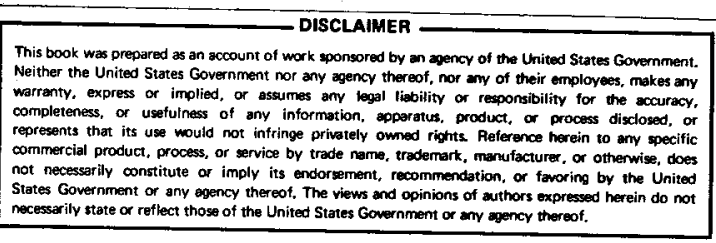

George R. Jiracek*

EARTH SCIENCE LABORATORY

UNIVERSITY OF UTAH RESEARCH INSTITUTE

420 Chipeta Way, Suite 120

Salt Lake City, Utah 84108

Date Published - September, 1979

\author{
Prepared for the \\ DEPARTMENT OF ENERGY \\ DIVISION OF GEOTHERMAL ENERGY \\ UNDER CONTRACT DE-ACO7-78ET-28392 \\ (formerly EG-78-C-07-1701)
}

\footnotetext{
*Permanent Address: Department of Geology, University of New Mexico Albuquerque, New Mexico 87131.
} 


\section{DISCLAIMER}

This report was prepared as an account of work sponsored by an agency of the United States Government. Neither the United States Government nor any agency Thereof, nor any of their employees, makes any warranty, express or implied, or assumes any legal liability or responsibility for the accuracy, completeness, or usefulness of any information, apparatus, product, or process disclosed, or represents that its use would not infringe privately owned rights. Reference herein to any specific commercial product, process, or service by trade name, trademark, manufacturer, or otherwise does not necessarily constitute or imply its endorsement, recommendation, or favoring by the United States Government or any agency thereof. The views and opinions of authors expressed herein do not necessarily state or reflect those of the United States Government or any agency thereof. 


\section{DISCLAIMER}

Portions of this document may be illegible in electronic image products. Images are produced from the best available original document. 
NOTICE

This report was prepared to document work sponsored by the United States Government. Neither the United States nor its agent, the United States Department of Energy, nor any Federal employees, nor any of their contractors, subcontractors or their employees, makes any warranty, express or implied, or assumes any legal liability or responsibility for the accuracy, completeness, or usefulness of any information, apparatus, product or process disclosed, or represents that its use would not infringe privately owned rights.

NOTICE

Reference to a company or product name does not imply approval or recommendation of the product by the University of Utah or the U.S. Department of Energy to the exclusion of others that may be suitable. 
TABLE OF CONTENTS

Page

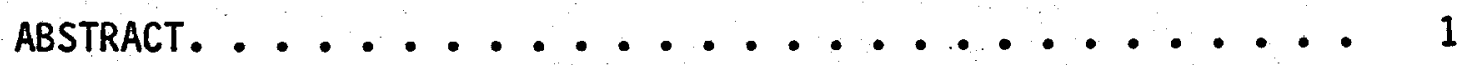

INTRODUCTION. . . . . . . . . . . . . . . . . 2

METHOD OF CALCULATION . . . . ............. 4

THEORETICAL MODELS. ............... .77

Bipole Orientation ................ 8

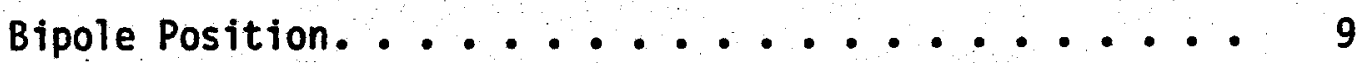

Depth. . . . . . . . . . . . 10

Resistivity Contrast .............. 10

Depth Extent .................. 11

Smal1 Bodies .................... 11

Complex Bodies . . . . . . . . . . . . 11

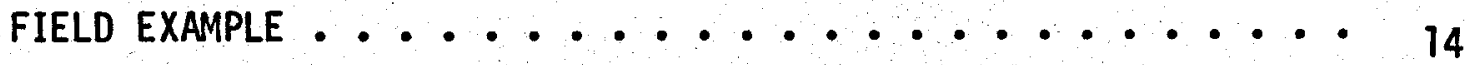

ACKNOWLEDGEMENTS. $\ldots \ldots \ldots$

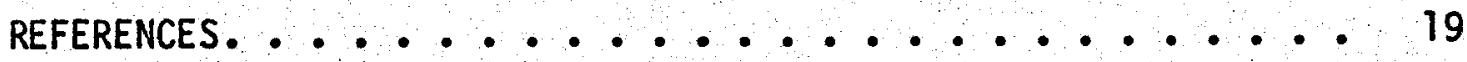




\section{ABSTRACT}

We have studied the bipole-dipole responses of three-dimensional (3D) prisms using an integral equation numerical solution. Although response patterns are quite complex, the bipole-dipole method appears to be a useful, efficient means of mapping the areal distribution of resistivity. However, 30 modeling is required for quantitative interpretation. Computer time for our solution varies from negligible for small bodies to 6 minutes on a UNIVAC 1108 for the largest possible body ( 85 cubes).

Bipole-dipole response varies significantly with bipole orientation and position, but simply changing the distance between the bipole and the body does not greatly affect the response. However, the response is complex and interpretation ambiguous if both transmitter electrodes are located directly over a body. Boundaries of shallow bodies are much better resolved than those of deep bodies. Conductive bodies produce "false" polarization highs that can confuse interpretation. It is difficult to distinguish the effects of depth and resistivity contrast, and, as with all electrical methods, depth extent is difficult to resolve.

Interactive interpretation of bipole-dipole field results from a geothermal prospect in New Mexico illustrates the value of the 3D modeling technique. 
INTRODUCTION

The bipole-dipole method is a technique for rapidly mapping the areal distribution of electrical resistivity. It has been used extensively in geothermal exploration in the past but has fallen out of favor because the apparent resistivity patterns are usually complex and difficult to interpret. If the data can be interpreted though, the bipole-dipole method is an efficient means of mapping resistivity, particularly in rugged terrain, because the transmitter can be placed at an easily accessible location and only the receiver moved. This increased efficiency is gained, of course, at the expense of resolution.

Examples of the successful application of the bipole-dipole method are given by Risk et al. (1970), Keller et al. (1975), Stanley et al. (1976), Jiracek and Smith (1976), and Meidav (1979). However, the only model studies for interpretation have been for outcropping two-dimensional (2D) dikes (Keller et al,, 1975), hemispherical sinks (Risk et a1,, 1970), and general 2D models (Dey and Morrison, 1977). In an attempt to circumvent interpretation problems, Keller and Furgerson (1977) used a rotating bipole source and Doicin (1976) developed a quadripole-quadripole method.

Apart from an inherent lack of resolution, the main limitation of the bipole-dipole method has been a lack of realistic interpretational models. Hence, to gain interpretation insight, we have computed bipole-dipole responses from three-dimensional (30) prisms. Our integral equation solution is capable of calculating the response of one or several 3D prisms at reasonable computer costs. With it we have calculated a catalog of 
models and have interpreted data from a geothermal prospect using an interactive computer terminal.

In this report we briefly discuss the numerical modeling technique, and then elucidate important aspects of apparent resistivity patterns for a series of 30 models. Finally, we present the results of interactive interpretation of bipole-dipole data from the Las Alturas Estates geothermal prospect in New Mexico. 
METHOD OF CALCULATION

The integral equation solution that we used to simulate the bipole-dipole response of three-dimensional bodies has been described by Hohmann (1975). The integral equation is formulated by replacing an inhomogeneity by a volume of polarization currents. The polarization current is found via the method of moments with pulse basis functions and delta weight functions. Then the secondary electric field at the surface of the earth is obtained by utilizing the appropriate half-space dyadic Green's function and treating the polarization current as the source of the secondary field.

Because it is necessary to solve for the polarization current only in the inhomogeneity, the integral equation method is well suited to evaluating a field technique using simple prism models. However, the computer program also can be used to interpret data interactively in term of a number of prisms. In either case, the cubic cells into which the prisms are divided can be made large at depth to reduce computer time.

Figure 1 shows the simple model geometry. The earth is taken to be a half-space of resistivity $p_{1}$, containing a buried prism with resistivity $P_{2}$. Relevant dimensions are depth $D$, width $W$, strike length $L$, and depth extent DE. Multiple prisms can be modeled, and if they are far enough apart, interactions among them can be ignored to reduce computer time.

The bipole transmitter is a grounded wire two units in length, while the receiver is a pair of short, orthogonal grounded wires. For our calculations we assume that the receiver measures orthogonal electrical field components at a point. 
field components at a point.

Apparent resistivity is based on the total electric field, obtained by adding the orthogonal components vectorially. Any two arbitrary field directions can also be used to obtain the total field. For a homogeneous earth having resistivity $\rho$, the $x$ and $y$ components of electric field at the receiver in Figure 1 are given by

$E_{x}=\frac{\rho I}{2 \pi}\left\{\frac{x-x_{2}}{\left[\left(x-x_{2}\right)^{2}+\left(y-y_{2}\right)^{2}\right]^{3 / 2}}-\frac{x-x_{1}}{\left[\left(x-x_{1}\right)^{2}+\left(y-y_{1}\right)^{2}\right]^{3 / 2}}\right\}$

$=\frac{\rho I}{2 \pi} Q_{X}$

$E_{Y}=\frac{\rho I}{2 \pi}\left\{\frac{y-y_{2}}{\left[\left(x-x_{2}\right)^{2}+\left(y-y_{2}\right)^{2}\right]^{3 / 2}}-\frac{y-y_{1}}{\left[\left(x-x_{1}\right)^{2}+\left(y-y_{1}\right)^{2}\right]^{3 / 2}}\right\}$

$=\frac{\rho I}{2 \pi} Q_{y}$

Thus the total electric field is given by

$$
E=\left(E_{x}^{2}+E_{y}^{2}\right)^{T / 2}=\frac{\rho I}{2 \pi}\left(Q_{x}^{2}+Q_{y}^{2}\right)^{T / 2}
$$

and the apparent resistivity is given by

$$
\rho_{a}=\frac{2 \pi E}{I\left(Q_{x}^{2}+Q_{y}^{2}\right)^{1 / 2}}
$$

Computer storage limitation on the University of Utah UNIVAC 1108 computer is 85 cells. As figure 2 shows, computation time is negligible for a small number of cells and 6 minutes for 80 cells. The major components of the computer time are matrix formulation, matrix 
factorization, and calculation of the secondary field (on a $15 \times 15$ grid for Figure 2).

Convergence checks and comparisons with other numerical solutions (Hohmann, 1975) indicate that the results are valid. 
THEORETICAL MODELS

Looking at apparent resistivity response in terms of our integral equation solution provides a valuable intuitive feeling for bipole-dipole anomalies. The measured potential is the sum of two potentials: primary and secondary. The primary potential is what would be measured if the earth were homogeneous, whereas the secondary potential represents the contribution from the inhomogeneity. The secondary potential originates at polarization dipoles distributed throughout the body or, equivalently, at surface charges on the body. For a conductive body the polarization dipoles are oriented in roughly the same direction as the primary field, as shown in Figure 3. For a resistive body the dipoles are oriented in the opposite direction.

An apparent resistivity low is to be expected over a conductive body where the secondary field is in the opposite direction from the primary field, as shown in Figure 3. Furthermore, we expect an apparent resistivity high beyond the body from the transmitter, because the secondary field is in the same direction as the incident field. The opposite patterns occur for a resistive body. Hence, we should expect to see "false" apparent resistivity polarization highs and lows in bipole-dipole surveys and theoretical studies.

Figure 3 also indicates the conditions under which the boundaries of a body can be delineated. High apparent resistivity gradients are to be expected over a surface charge concentration, which depends on the component of electric field normal to a resistivity discontinuity. Hence, 
resistivity boundaries normal to the primary field will be better resolved than boundaries parallel to the primary field.

Referring to Figure 1, we see that the important parameters to be analyzed in a 30 model study are the transmitter orientation and position along with the depth, width, length, depth extent, and resistivity contrast of the body. In the following series of models we show the effects of changes in these parameters on the bipole-dipole response pattern. The effects of width and length are illustrated by comparing the responses of square and rectangular bodies and by studying two-prism models.

Except where stated otherwise, the background resistivity is 100 ohm-m, while the body resistivity is $10 \mathrm{ohm}-\mathrm{m}$. The transmitter bipole is 2 units long and, except where stated otherwise, the depth of the body is one unit. The square body has dimensions $4 \times 4 \times 1$ (WxLXDE), while the dimensions of the rectangular body are $2 \times 8 \times 2$ units. Arrows show the direction of the total electric field. A heavy black line marks the transmitter location for each apparent resistivity map.

\section{Bipole Orientation}

Figures 4 and 5 show responses with four different bipole transmitter orientations, for square and rectangular bodies, respectively. In each case there is an apparent resistivity low over the body. The boundary of the body is better resolved (by steep gradients) where the electric field is more nearly perpendicular to the boundary, as shown by the arrows. The pattern of the apparent resistivity low changes somewhat with bipole orientation, but the changes in the position and amplitude of the 
polarization high are much more notable. Polarization highs are necessarily adjacent to the steepest gradients on the maps.

As 11 lustrated in Figures 4 and 5 , bipole orientation can affect the response in a misleading way. For example, as shown by figure 4B, elongated contours do not necessarily imply an elongated body. However, 3D interpretation models should enable one to cope with these effects.

\section{Bipole Position}

Fortunately, changing the distance between the bipole and the body does not have a great impact on the response, as shown by figure 6 . The only significant change occurs when one transmitter electrode is placed over the body (Figure 6A).

Figure 7 illustrates, for a square body, the effect of changing the position of the bipole with respect to the body. As expected, the pattern changes with bipole position, but 30 modeling should allow one to interpret such data.

As Figure 8 shows, when both transmitting electrodes are over a body, interpretation is ambiguous. The response pattern consists of the familiar layered-earth "peanut" shape around the electrodes (Zohdy, 1978), and low apparent resistivities elsewhere. The "peanut" shape, which expands away from the body as an electrode approaches the edge of the body, is due to the greater influence of the host rock as the receiver nears a transmitter electrode. Since this is a similar pattern to that produced by a layered earth, positioning a bipole transmitter over a conductive target is 
undesirable.

Figure 9 shows the effect of transmitter distance for a rectangular body. Again, distance does not have a great impact unless an electrode is located over the body.

Figures 10 and 11 illustrate the effect of bipole position on the response of a rectangular body with the bipole oriented perpendicular and parallel, respectively, to the long axis of the body. The response pattern changes drastically with bipole position and orientation, which is one reason bipole-dipole data have been so misleading and difficult to interpret.

In Figure 12 the bipole is positioned at four different locations over a rectangular body. As was the case for the square body (Figure 8), the response patterns do not indicate the areal extent of the body when both transmitter electrodes are located over it.

Depth

Responses for four depths: $0.5,1,2$, and 3 units are shown in Fugures 13 and 14 for square and rectangular bodies, respectively. Increasing the depth to the top of the body smooths and decreases the amplitude of the anomaly. As expected, the boundaries of the body are better resolved when it is shallow.

\section{Resistivity Contrast}

Figures 15 and 16 show theoretical bipole-dipole anomalies for square and rectangular bodies, respectively, with four different resistivity 
contrasts: $p_{2} / p_{1}=0.01,0.1,10$, and 100 . Three major conclusions may be drawn from these figures. First, changing the resistivity contrast mainly changes the amplitude of the anomaly; the pattern changes very little. Second, the "false" polarization highs associated with conductive bodies often have greater amplitude than "real" highs over resistive bodies. And finally, as comparison of Figure $13 \mathrm{~A}$ with $15 \mathrm{~A}$ and $14 \mathrm{~A}$ with $16 \mathrm{~A}$ shows, it is difficult to distinguish the effects of restivity contrast and depth.

\section{Depth Extent}

Depth extent is difficult to determine. Even with higher resolution electrical techniques such as use of the dipole-dipole array. Figures 17 and 18 show bipole-dipole anomalies for square and rectangular prisms, respectively, with depth extents of $1,2,3$, and 4 units. An important observation is that, although the apparent resistivity low changes very little with depth extent, the position and amplitude of the polarization high changes significantly. This characteristic may enable the interpreter to estimate depth extent and provides incentive for collecting such data in the field.

\section{Small Bodies}

Figures 19 and 20 11lustrate the responses of small square and rectangular bodies. They should be compared with figures 7,10 , and 11 for larger bodies.

\section{Complex Bodies}

Inhomogeneities in the earth are, of course, more complex than the simple models we have considered in Figures 4-20. The major purpose of 
bipole-dipole work is to del ineate the boundaries of arbitrary conductive bodies. Figure 21 illustrates the resolution one would achieve for a body composed of the conductive square and rectangular bodies considered above.

Note first that the actual outline of the body is more apparent when the transmitter bipole is oriented parallel to the long axis of the rectangular body (Figures $21 \mathrm{~B}, \mathrm{D}$ ). Because the anomaly pattern changes with bipole orientation, techniques such as the quadripole method suggested by Doicin (1976) or the rotating dipole method (Keller and Furgerson, 1977) which utilize more than one bipole orientation may be necessary for qualitative interpretations. However, these methods require more time for data collection.

As expected, resolution is better for the shallow body (Figure 21A, B), thus emphasizing that the real forte of the bipole-dipole method is delineating the areal extent of shallow conductive zones.

Finally, Figure 22 illustrates the resolution of combined shallow conductive and resistive bodies. In Figure 22A, $B$ an elongated resistive body is positioned between the bipole and a conductive body of interest. Both bodies are well resolved and, comparing Figure 22A with 13A, we see that the anomaly of the conductive body is not greatly altered by the resistive body.

In figures 22C, D a conductive body is situated between the bipole and a resistive body. Comparing Figure $22 \mathrm{C}$ with $14 \mathrm{~A}$ shows that the anomaly due to the conductive body is largely unaffected by the resistive body. However, the conductor effectively screens the resistive body so that it 
produces only a negligible anomaly. The response is less than that of an identical isolated body which is deeper (Figure 15C). 


\section{FIELD EXAMPLE}

To fllustrate the utility of the three-dimensional integral equation method in the interpretation of actual bipole-dipole field data, we present an example from a geothermal prospect in New Mexico. Figure 23 is a base map of the Las Alturas Estates area on the east side of the Rio Grande Valley near Las Cruces, New Mexico. The proximity of New Mexico State University to the domestic wells producing warm water $\left(35^{\circ}\right.$ to $45^{\circ} \mathrm{C}$ ) from a shallow depth $(100 \mathrm{~m})$ motivated detailed electrical resistivity exploration of the prospect. Schlumberger soundings and dipole-dipole profiles were used in addition to bipole-dipole mapping. Three bipole-dipole transmitters were employed in the reconnaissance of the geothermal reservoir. The longest bipole used one of the hot wells as an electrode (Figure 23); the other two bipoles were located east of the hot wells and south of Tortugas Mountain (Figure 23).

The two total field apparent resistivity maps generated from the shorter bipoles each exceed $30 \mathrm{~km}^{2}$ area and are presented in Figures 24 and 25. The bipole of Figure 24 has one electrode over the conductive zone while both electrodes of the bipole transmitter of Figure 25 are over the conductor. In these and subsequent calculated maps, regions of $\rho_{a}$ less than $60 \mathrm{ohm}-\mathrm{m}$ are shaded by a dot pattern. Findings from the electrical surveys at Las Alturas Estates were initially sumarized by Smith et al. (1977) and analyzed by Smith (1977). A quantitative 3D interpretation was presented by Jiracek and Gerety (1978) at the Annual Geothermal Resources Council Meeting. 
A conductive region ( $<60$ ohm-m) marks the area of the hot wells in both Figures 24 and 25 . This zone is sharply circumscribed by a resistive pattern ( $>60$ ohm-m), especially in Figure 24 , on the east, north and west sides of the survey area. A separate conductive basin is mapped northeast of Tortugas Mountain. Three-dimensional modeling was applied interactively to these results to determine to what extent the observed patterns reflect the true subsurface resistivity distribution, i.e., the areal extent of the shallow geothermal reservoir.

Figure 26 shows a plan view of the 30 model used to approximate the conductive geothermal reservoir. This model was defined from the combined Schlumberger and dipole-dipole 10 and 20 modeling and by a comparison of the observed bipole-dipole patterns with theoretical results (Figures 4-22). The reservoir is approximated by a slab of $10 \mathrm{ohm}-\mathrm{m}$ material which is $100 \mathrm{~m}$ deep $(D)$ and $500 \mathrm{~m}$ thick $(D E)$. The body has a length $(L)$ of $6 \mathrm{~km}$ and width $(W)$ of $2.5 \mathrm{~km} ; 600.5-\mathrm{km}$ cubes were used to model the conductive zone. The more complex resistive body of $300 \mathrm{ohm}-\mathrm{m}$ to the east of the conductive slab in Figure 26 models the resistive limestone of Tortugas Mountain and its buried extension to the south. The final total of 81 conductive and resistive cubes were immersed in a half-space of $75 \mathrm{ohm}-\mathrm{m}$. The simple model presented in figure 26 does not attempt to detail either the more complex near-surface $(<100 \mathrm{~m})$ variations or the conductive basin to the northeast beyond Tortugas Mountain (Figures 24 and 25).

Even so, a comparison of the theoretical results in Figures 27 and 28 with the field data of Figures 24 and 25 reveals a remarkable resemblance. This is more evident when comparing Figures 24 and 27 . It is apparent that 
the actual body is wider than the $2.5-\mathrm{km}$ body modeled and may extend farther to the south. However, the $60 \mathrm{ohm}-\mathrm{m}$ contour may be considered as very nearly outlining the body. Again, we emphasize that no attempt was made to model the regions near the bipole electrodes which reflect shallow resistivity variations. Our main interest has been in duplicating the major patterns of the field results using all available constraints, e.g., Schlunberger, dipole-dipole, and drilling results.

Notice that the conductive zone is not nearly so well-defined in Figures 25 and 28 . Theoretical models, such as those in Figure 8, expose the difficulty in delineating conductive boundaries when both electrodes are placed over the body. This is the case with the NS bipole transmitter at Las Alturas Estates. The nearly EW bipole source in Figures 24 and 27 has a more desirable configuration, with only one electrode over the body; better delineation of the anomaly would have been accomplished with both bipole sources well removed from the body. The important problem of proper positioning of the bipole sources away from the conductive target can be solved by limited detailed surveying. For example, by dipole-dipole profiling, prior to bipole-dipole mapping. This aspect of doing some detailed surveying prior to bipole-dipole reconnaissance is contrary to the usual field practice.

Using the results from Figures 24 through 28 we are able to estimate the areal extent of the shallow Las Alturas geothermal anomaly to be $3 \mathrm{~km}$ in EW extent and $6 \mathrm{~km}$ (or more) NS. Furthermore, the domestic hot wells are located on the west side of the anomaly and the eastern edge of the reservoir coincides with the western margin of Tortugas Mountain. These 
observations are confirmed by the two dipole-dipole profiles (Jiracek and Gerety, 1978) and suggest a westward dipping fault along the western side of Tortugas Mountain with an extension to the south. This has been hypothesised (Jiracek and Gerety, 1978) as the circulation zone for geothermal fluids recharging the conductive reservoir at Las Alturas Estates.

Recently (C. Swanberg and P. Morgan, personal communications, 1979) six $30-\mathrm{m}$ thermal gradient holes and two deeper (305 and $366 \mathrm{~m}$ ) test holes have been drilled into the Las Alturas Estates anomaly. The results show increased temperature gradients eastward over the anomaly toward Tortugas Mountain consistent with the interpretation of the geothermal source along the western flank of the mountain. Gradients are $90^{\circ} \mathrm{C} / \mathrm{km}$ on the west side of the conductive body and exceed $400^{\circ} \mathrm{C} / \mathrm{km}$ in the upper $30 \mathrm{~m}$ toward the mountain. The highest temperature reached $63^{\circ} \mathrm{C}$ at the maximum depth of $305 \mathrm{~m}$ on the east side of the anomaly; land permitting considerations prevented any drilling closer than $1 \mathrm{~km}$ to Tortugas Mountain. Funds to use the Las Alturas Estates geothermal reservoir for space heating portions of New Mexico State University are presently being sought. 


\section{ACKNOWLEDGMENTS}

The theoretical work was funded by the Department of Energy, Division of Geothermal Energy, Contract DE-AC-07-78ET28392 (formerly, EG-78-C-07-1701).

The resistivity field results from Las Alturas Estates, New Mexico were collected through the efforts of several students from the University of New Mexico including M. E. Ander, M. T. Gerety, H. T. Halcombe, P. Parks, and T. Summers, Jr. and through Financial Survey Grant no. 14-08-0001-E-255 and New Mexico Energy Resource Development Grant UNM no. $117-69-B$. 


\section{REFERENCES}

Dey, A., and Morrison, H.F., 1977, An analysis of the bipole-dipole method of resistivity surveying: Geothermics, v.6, p. 47-81.

Doicin, D., 1976, Quadripole-quadripole arrays for direct current resistivity measurements-mode1 studies: Geophysics, v. 41, p. 79-95. Hohmann, G.W., 1975, Three-dimensional induced polarization and electromagnetic modeling: Geophysics, v. 40, p. 309-324.

Jiracek, G.R., and Smith, C., 1976, Deep resistivity investigations at two known geothermal resource areas (KGRAs) in New Mexico: Radium Springs and Lightning Dock: New Mexico Geol. Soc. Spec. Pub. No. 6, p. $71-76$.

Jiracek, G.R., and Gerety, M.T., 1978, Comparison of surface and downhole resistivity mapping of geothermal reservoirs in New Mexico: Geothermal Resources Council, Trans., v.2, p. 335-336. Keller, G.V., Furgerson, R.B., Lee, C.V., Harthill, N., and Jacobson, J.J., 1975, The dipole mapping method: Geophysics, v. 40, p. 451-472. Keller, G.V., and Furgerson, R.B., 1977, Determining the resistivity of a resistant layer in the crust: in The Earth's Crust, Amer. Geophys. Union Monogr. 20, ed. by J.G. Heacock, p. 440-469.

Meidav, T., 1979, Geothermal exploration of the Agua de Pau Massif, San Miguel, Azores, Portugal (abs.): Geophysics, v. 44, p. 403-404. Risk, G.F., MacDonald, W.J.P., and Dawson, G.B., 1970, D.C. resistivity surveys of the Broadlands geothermal region, New Zealand: Geothermics, v. 2, p. 287-294. Smith, C., 1977, On the electrical evaluation of three southern New 
Mexico geothermal resource areas: unpublished M.S. thesis, University of New Mexico, Albuquerque.

Smith C., Jiracek, G.R., and Ander, M.E., 1977, Deep electrical investigations of geothermal prospects in the Basin and Range province of southern New Mexico (abs.): Geophysics, v. 42, p. 183. Stanley, W.D., Jackson, D.B., and Zohdy, A.A.R., 1976, Deep electrical investigations in the Long Valley geothermal area, California: J. Geophys. Res., v. 81, p. 810-820. Zohdy, A.A.R., 1978, Total field resistivity mapping and sounding over horizontally layered media: Geophysics, v. 43 , p. 748-766. 


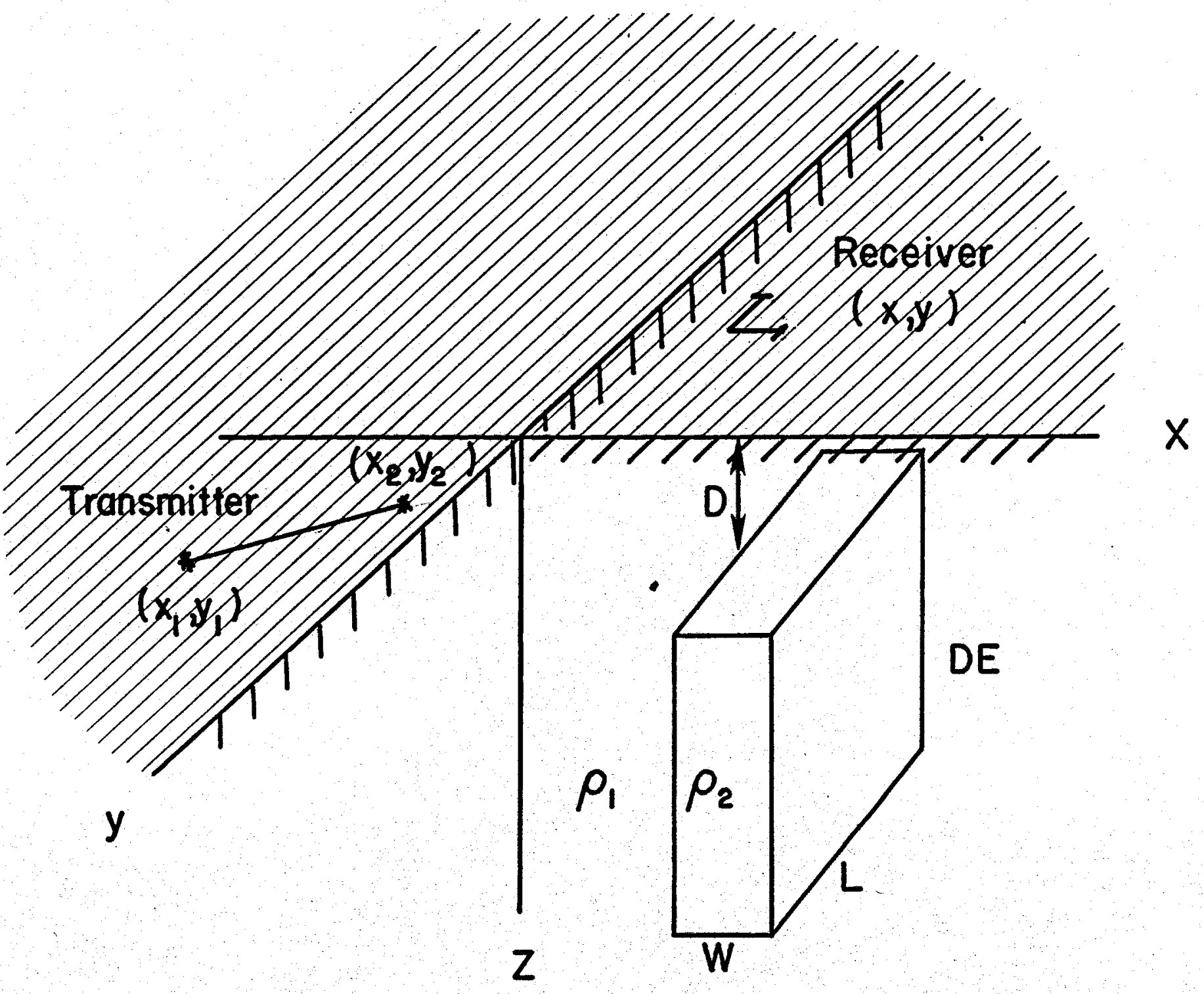

Figure 1. Bipole-dipole model geometry. 


$$
\varepsilon_{2}
$$




$$
1
$$




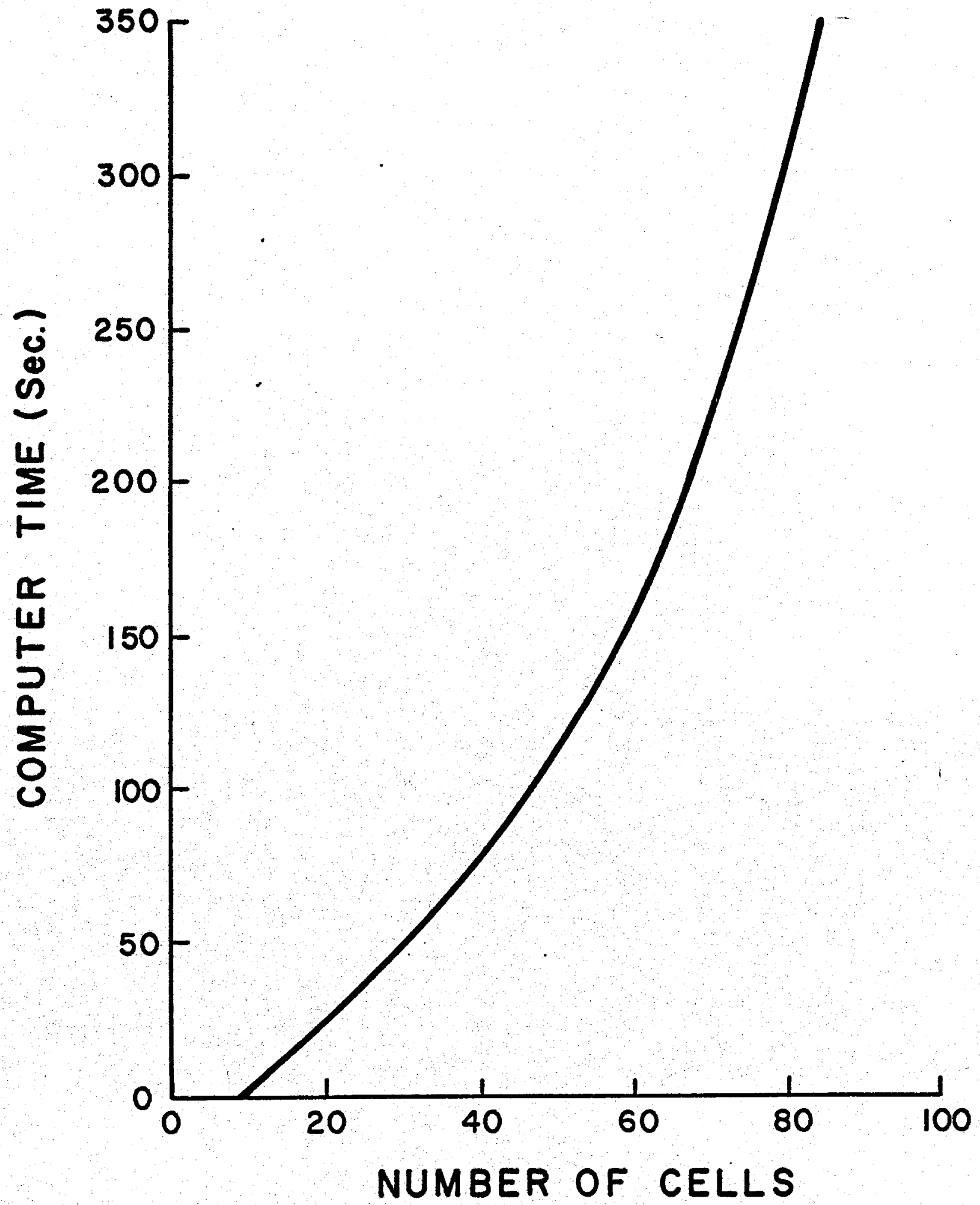

Figure 2. Computer time as a function of the number of subdivisions in a 30 body. 

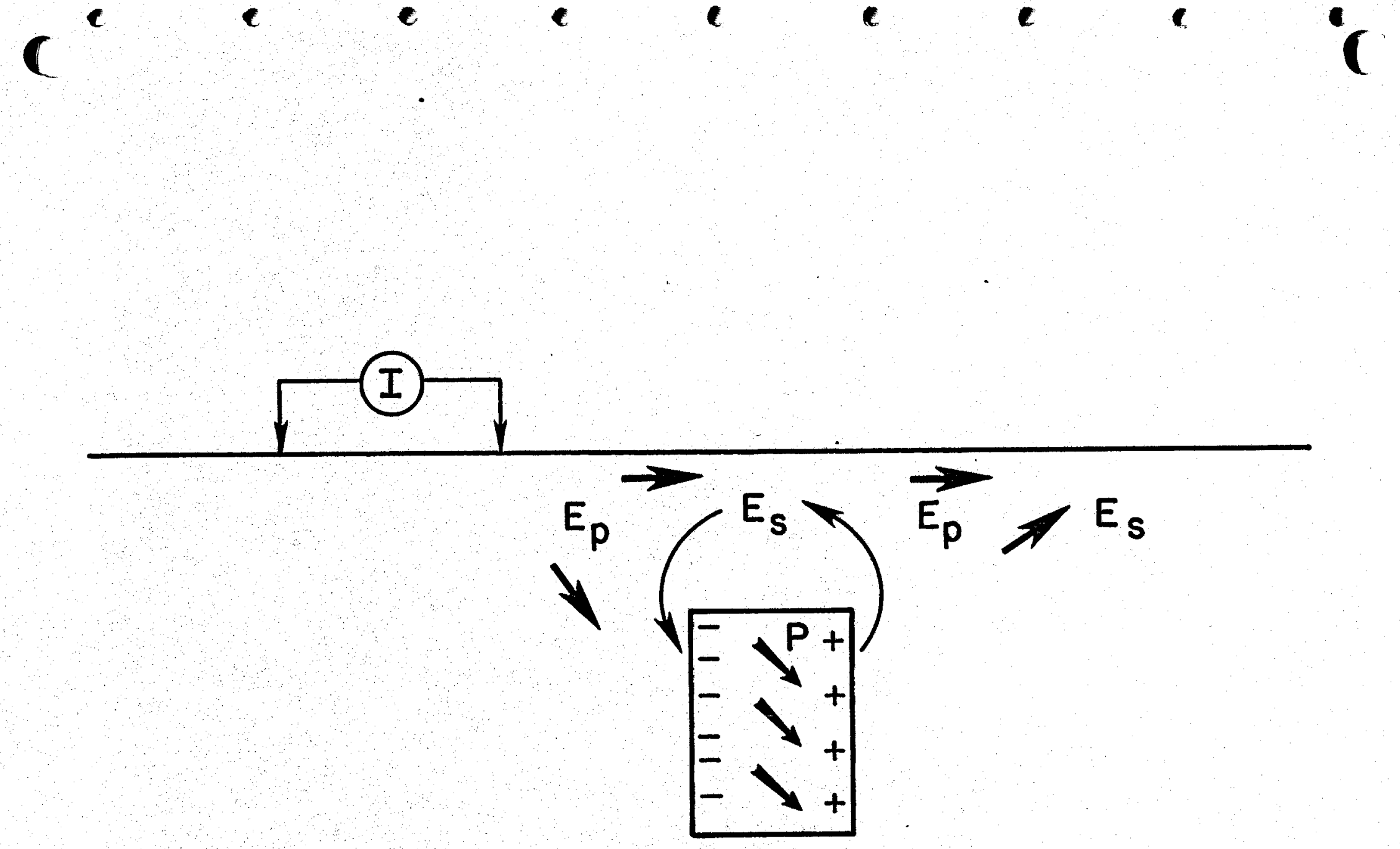

Figure 3. Sketch showing the geometry of primary and secondary fields. 


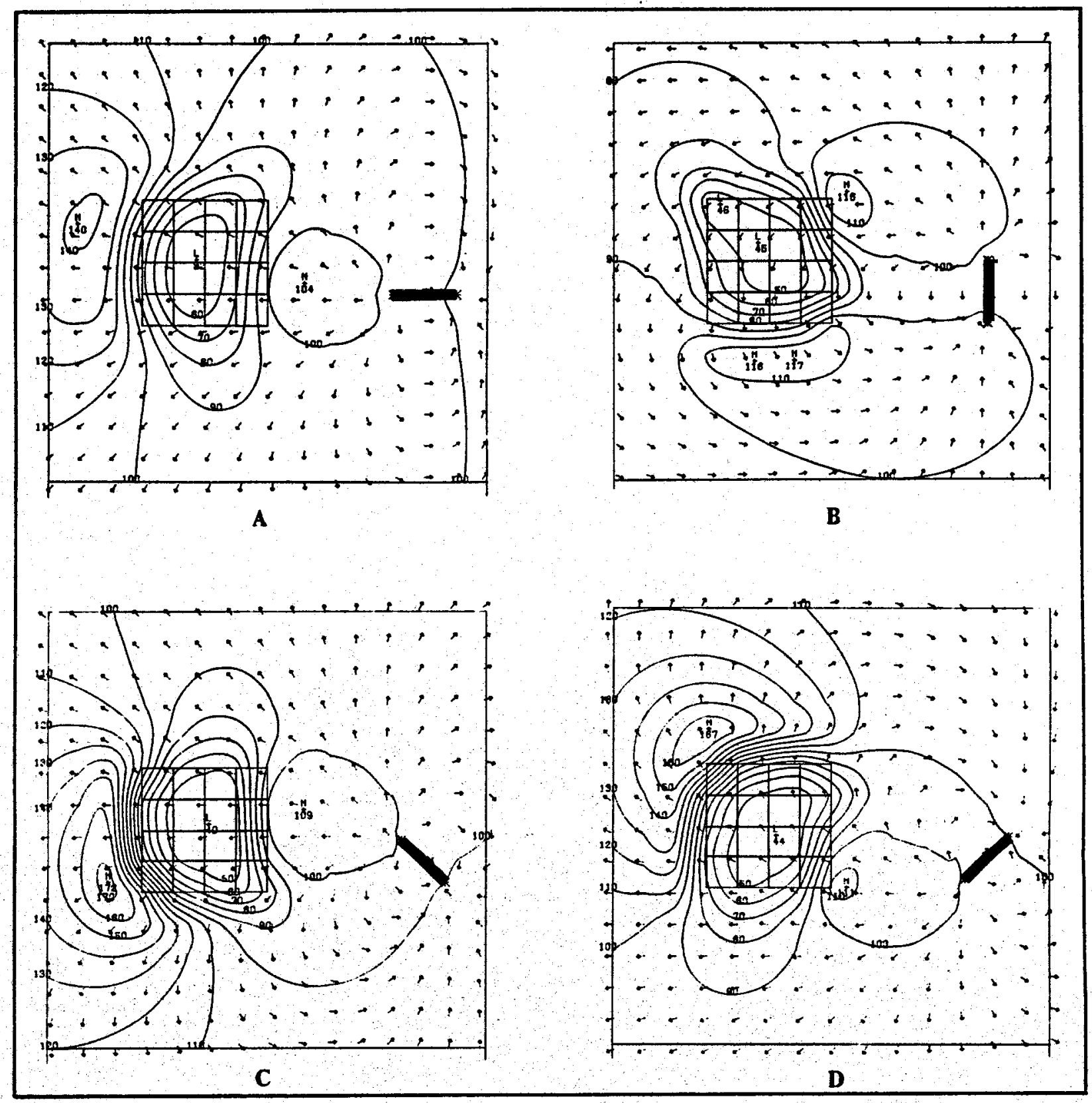

Figure 4. Effect of bipole orientation - square body: $W=4, L=4, D E=1, D=1$, $\rho_{2}=10, \rho_{1}=100$. 


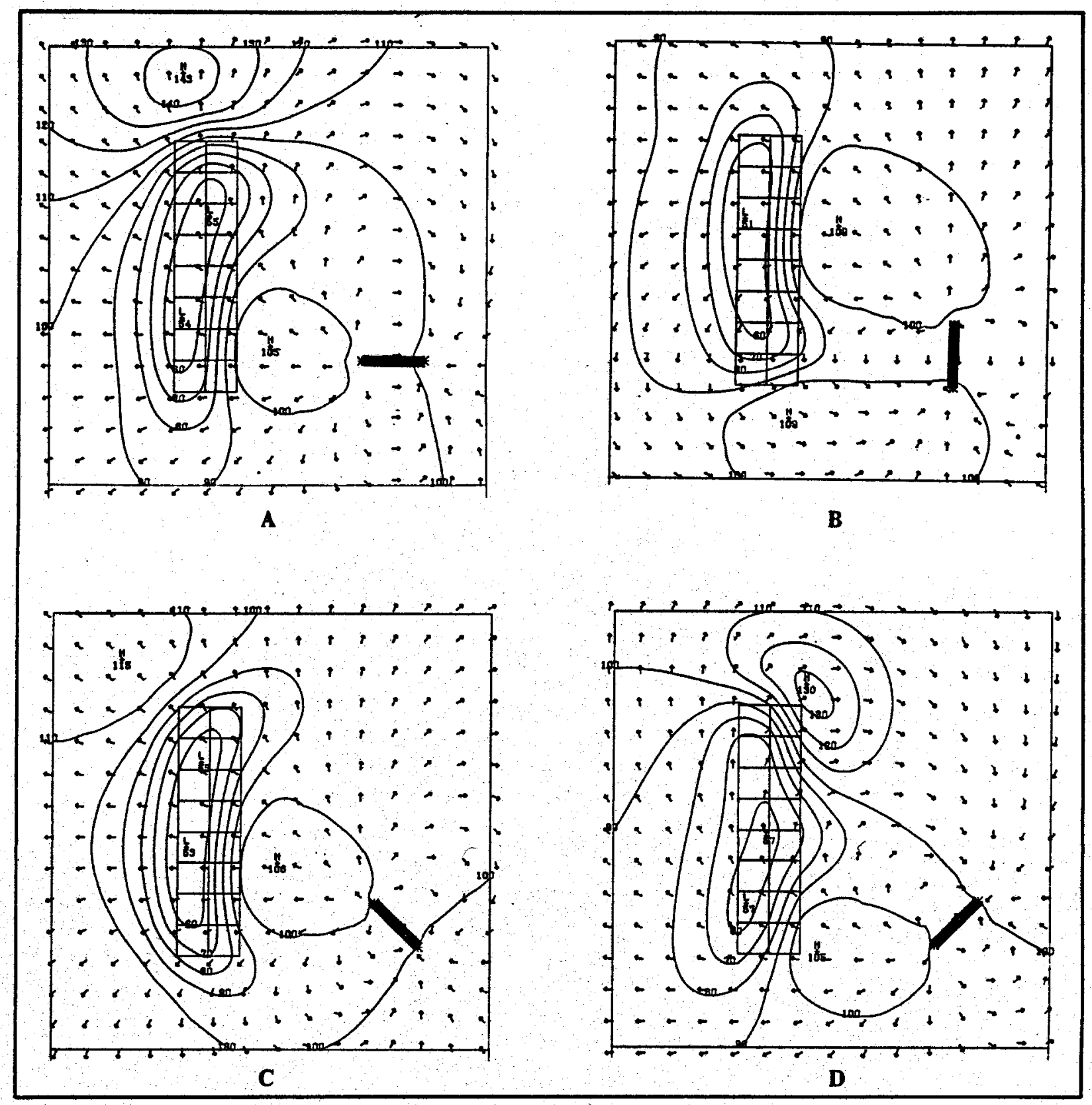

- Figure 5. Effect of bipole orientation - rectangular body: $W=2, L=8, D E=2$, - $D=1, \rho_{2}=10, \rho_{1}=100$. 


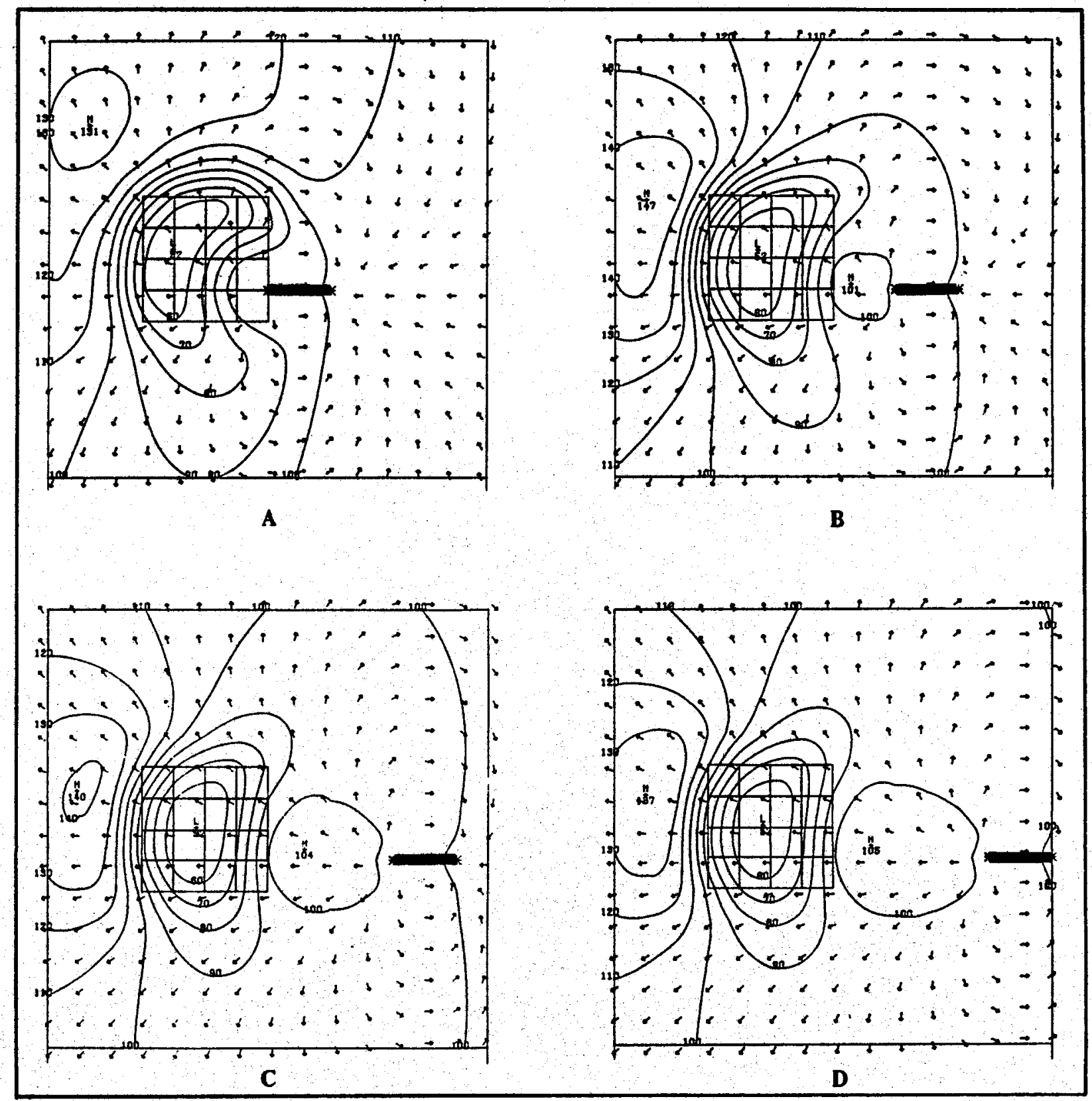

Figure 6. Effect of bipole distance - square body: $W=4, L=4, D E=1, D=1$, $\rho_{2}=10, p_{1}=100$. 


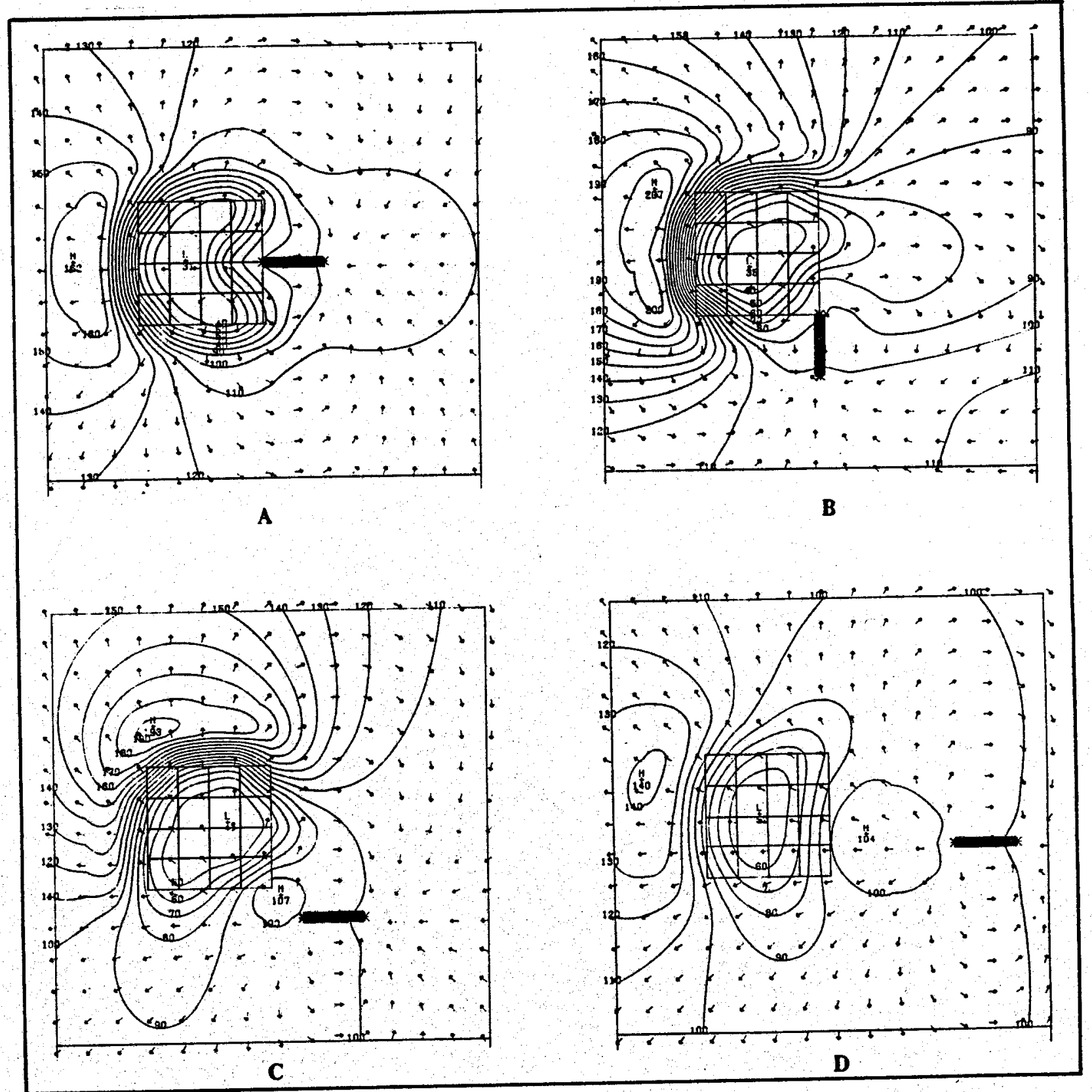

Figure 7. Effect of bipole position - square body: $W=4, L=4, D E=1, D=1$, $\rho_{2}=10, \rho_{1}=100$. 


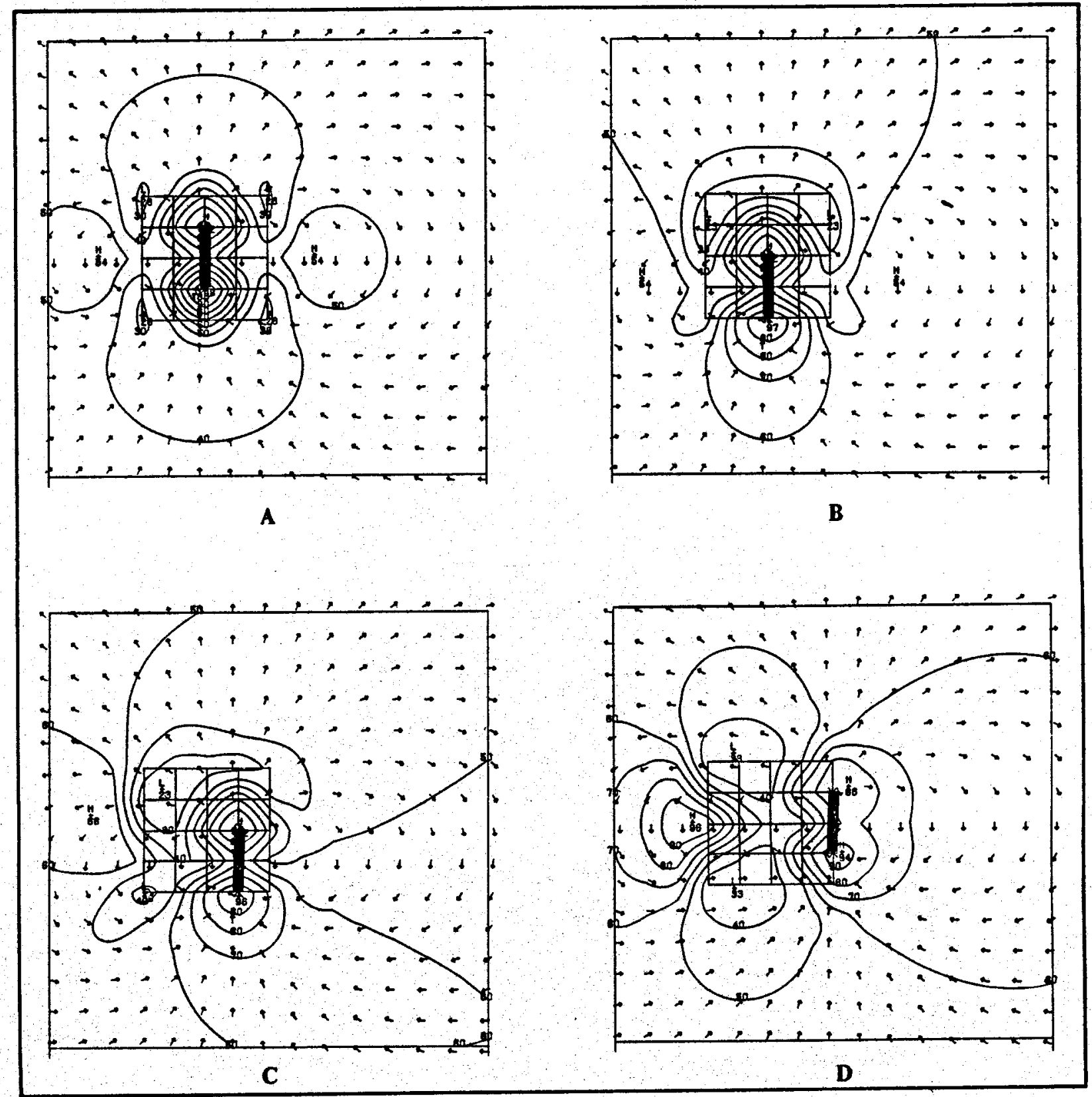

Figure 8. Bipole over a square body: $W=4, L=4, D E=1, D=1, \rho_{2}=10, \rho_{1}=100$. 


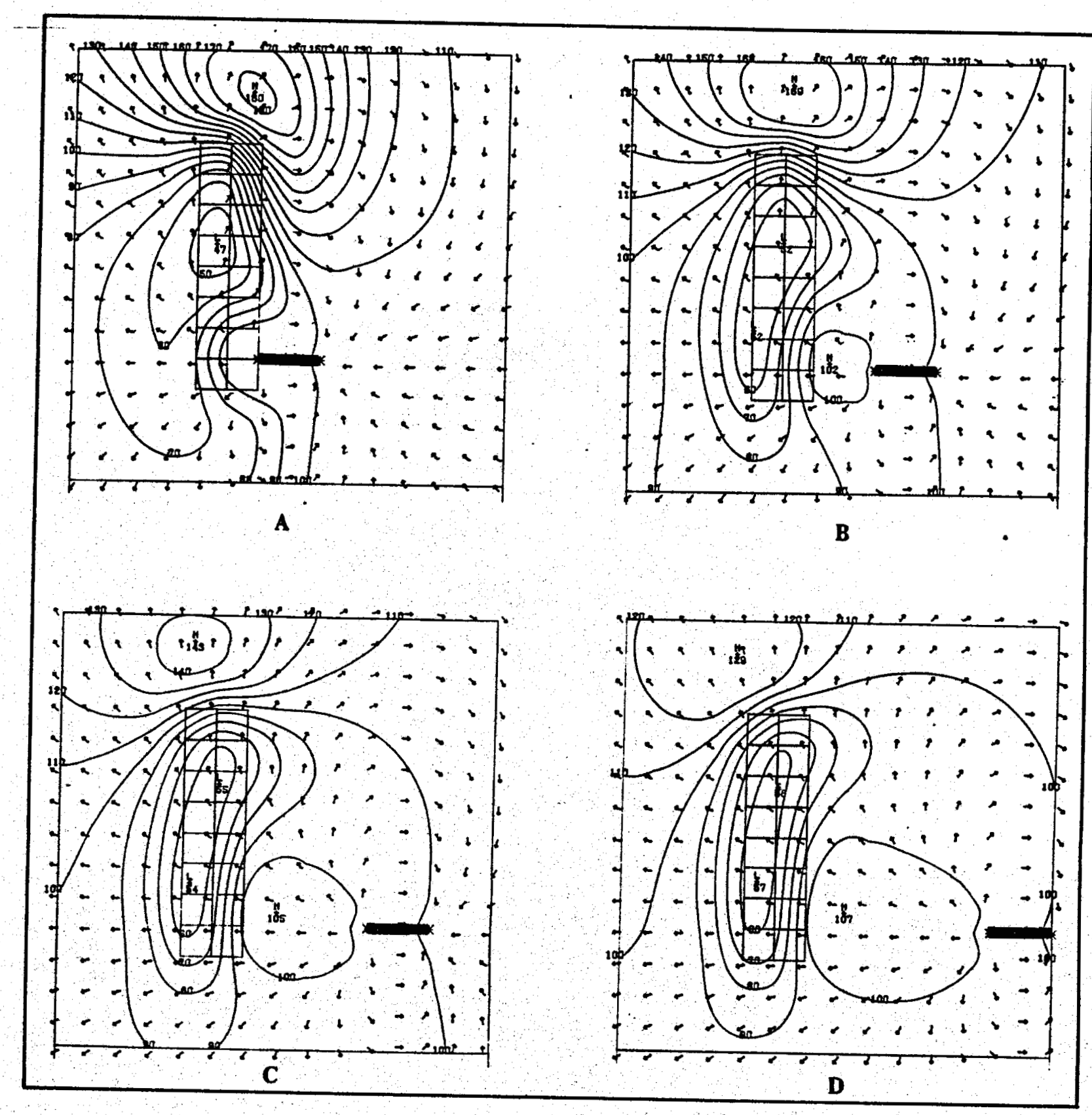

Figure 9. Effect of bipole distance - bipole perpendicular to long axis of rectangular body: $K=2, L=8, D E=2, D=1, \rho_{2}=10, \rho_{1}=100$. 


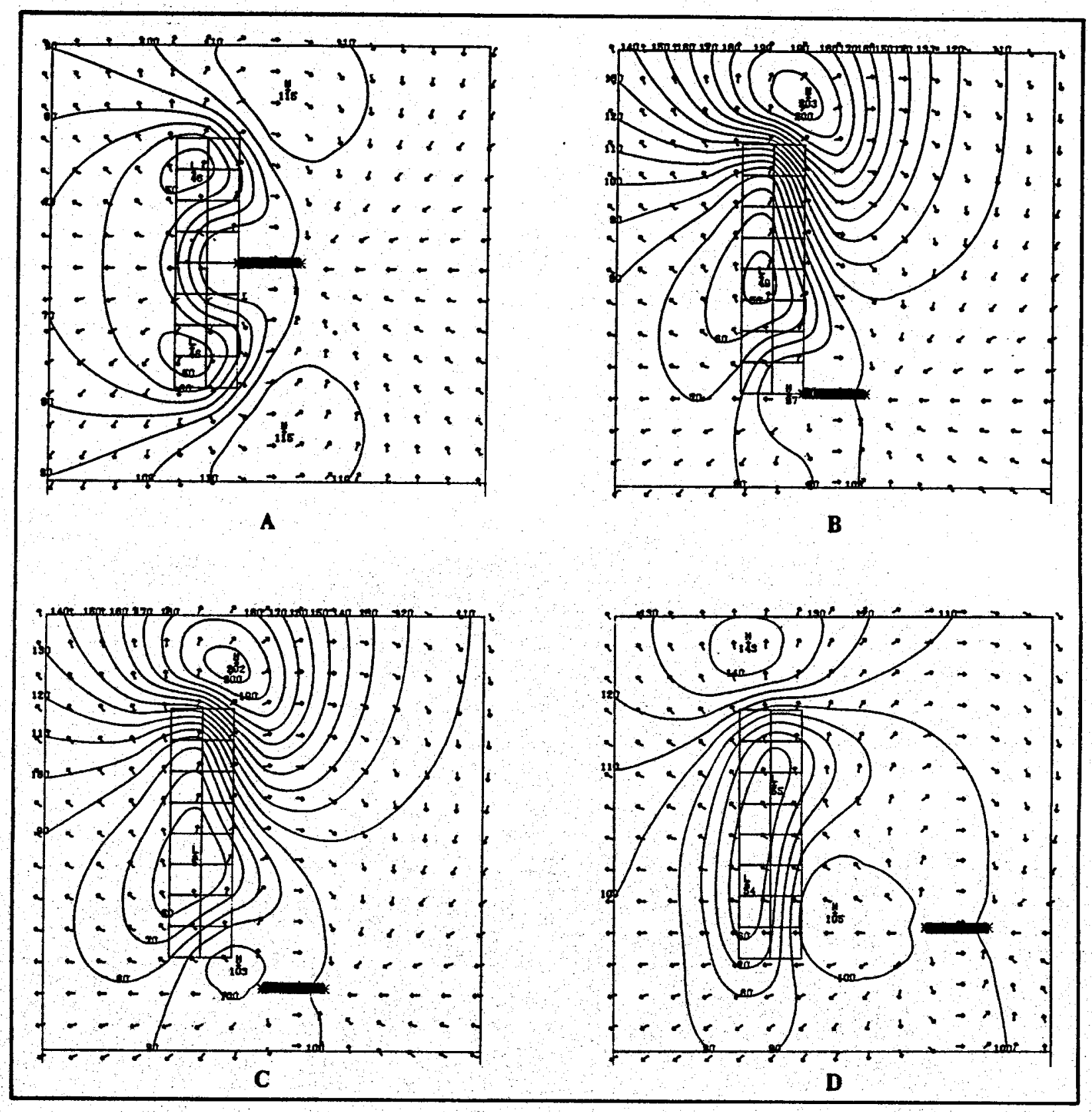

Figure 10. Effect of bipole position - bipole perpendicular to long axis of rectangular body: $W=2, L=8, D E=2, D=1, \rho_{2}=10, \rho_{1}=100$. 


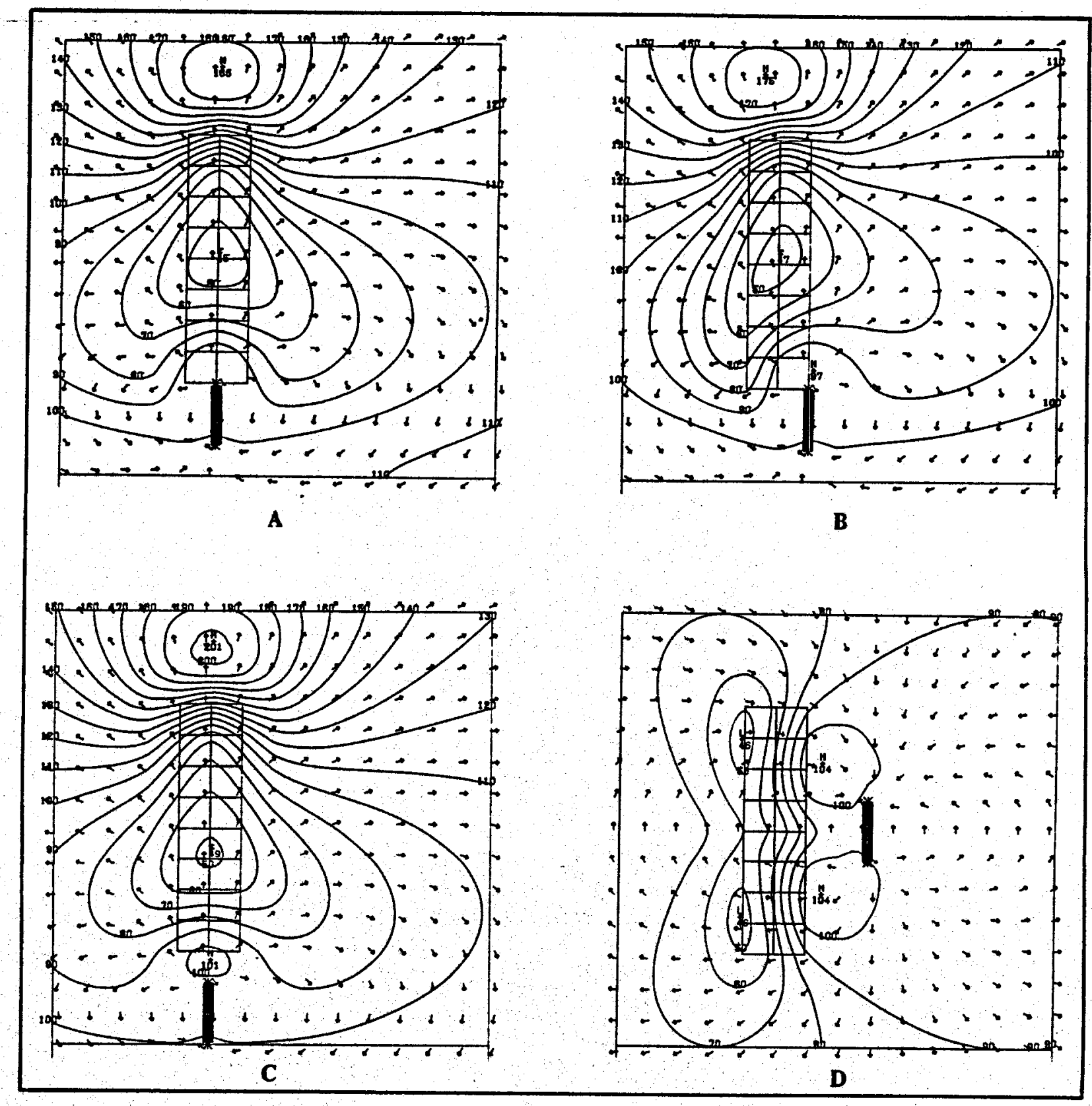

Figure 11. Effect of bipole position - bipole parallel to long axis of rectangular body: $W=2, L=8, D E=2, D=1, \rho_{2}=10, \rho_{1}=100$. 


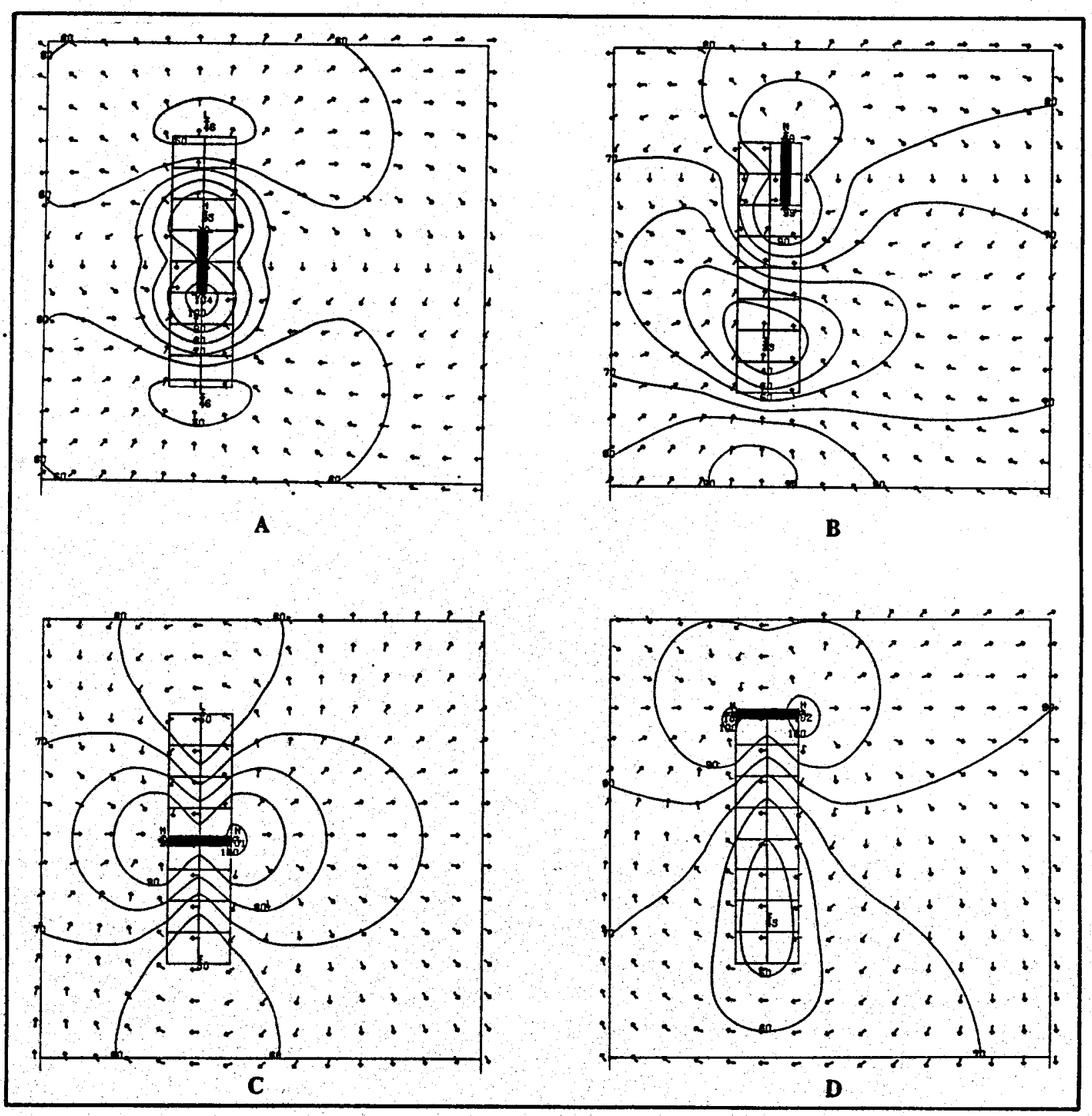

Figure 12. Bipole over a rectangular body: $W=2, L=8, D E=2, D=1, \rho_{2}=10$, $\rho_{1}=100$. 


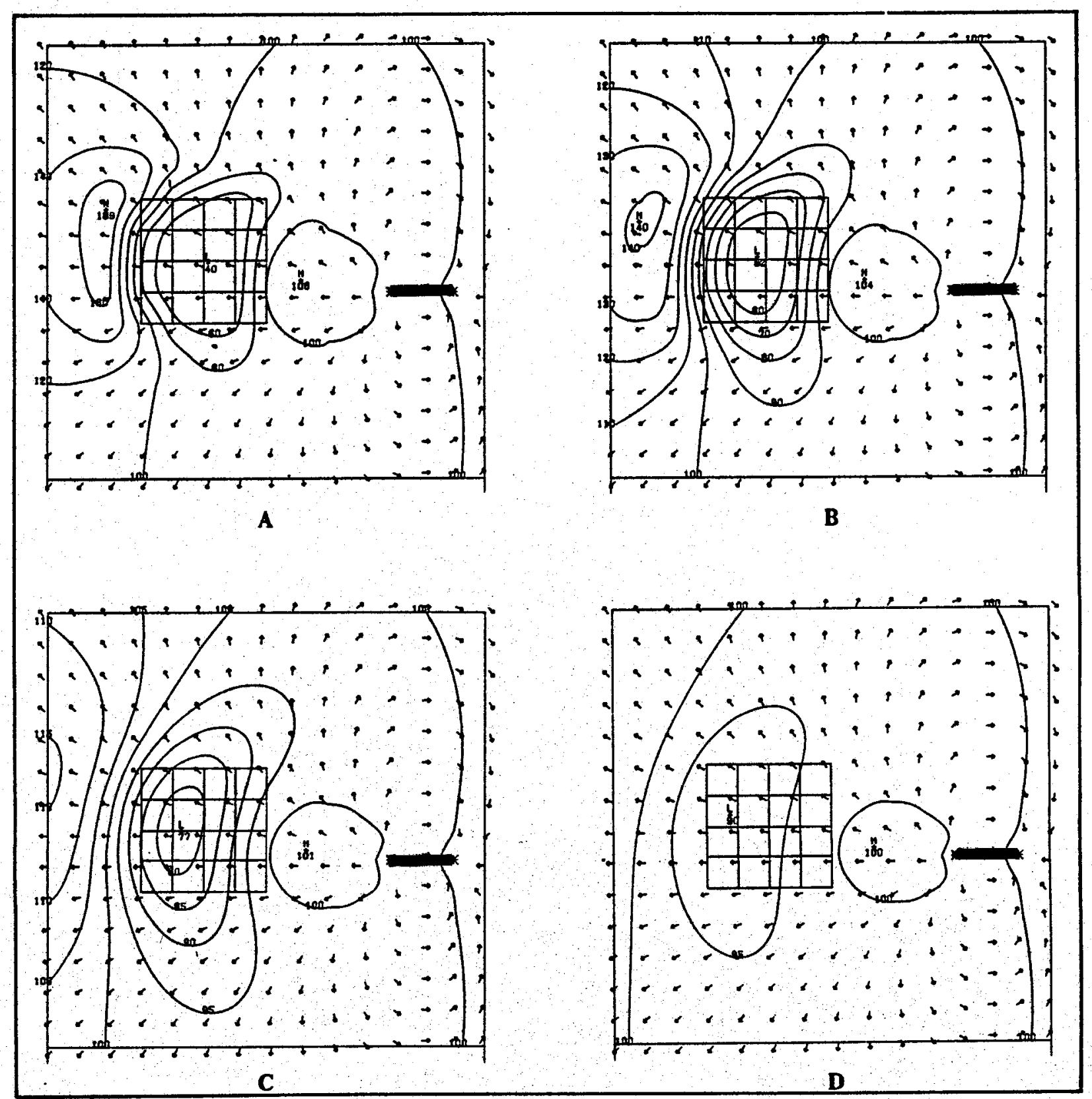

Figure 13. Effect of depth (D) - square body: $W=4, L=4, D E=1, \rho_{2}=10, \rho_{1}=100$; $A: D=0.5 ; B: D=1 ; C: D=2 ; D: D=3$. 


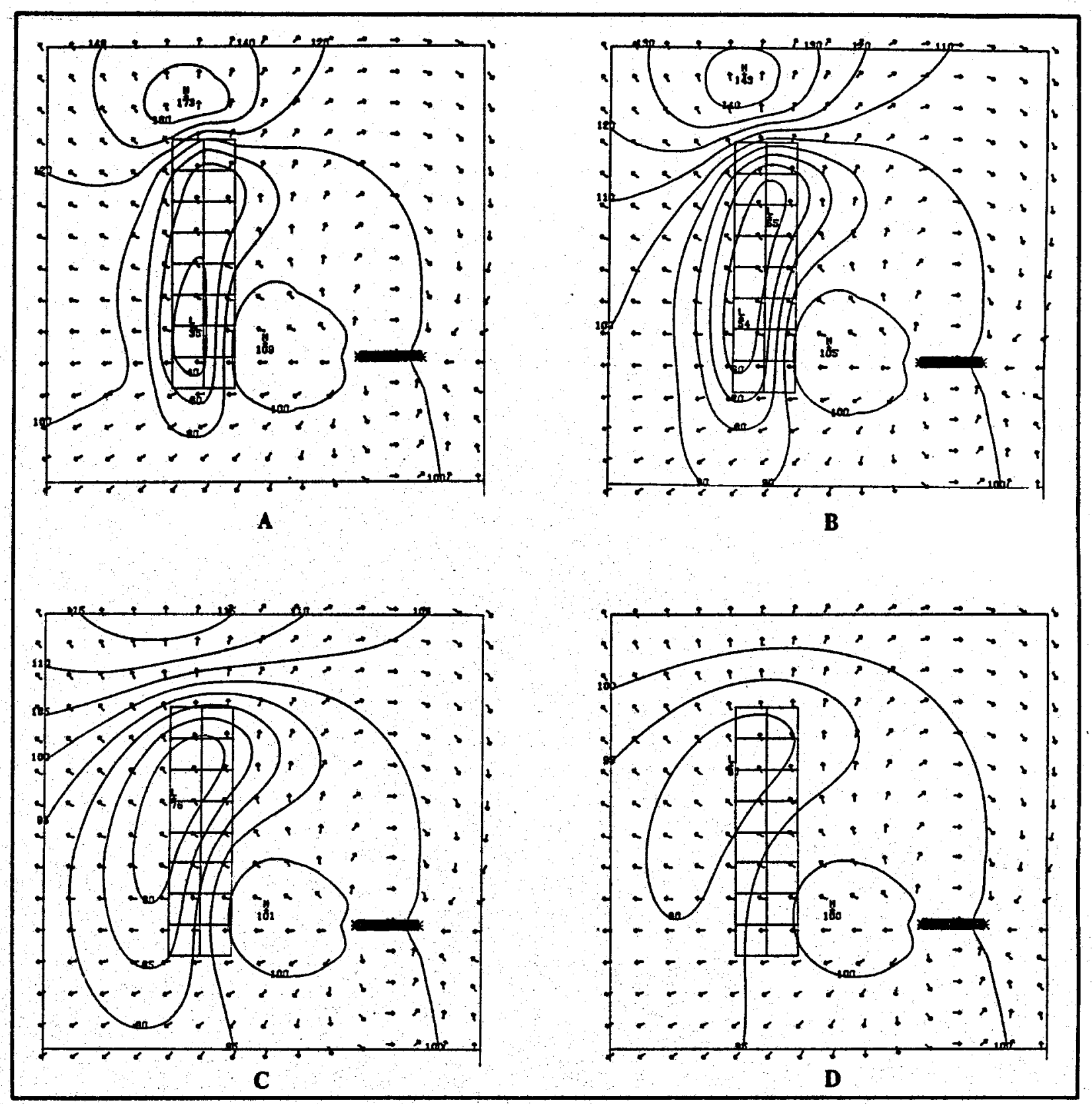

Figure 14. Effect of depth $(B)$ - rectangular body: $W=2, L=8, D E=2, \rho_{2}=10, \rho_{1}=100$; $A: D=0.5 ; B: D=1 ; C: D=2 ; D: D=3$. 


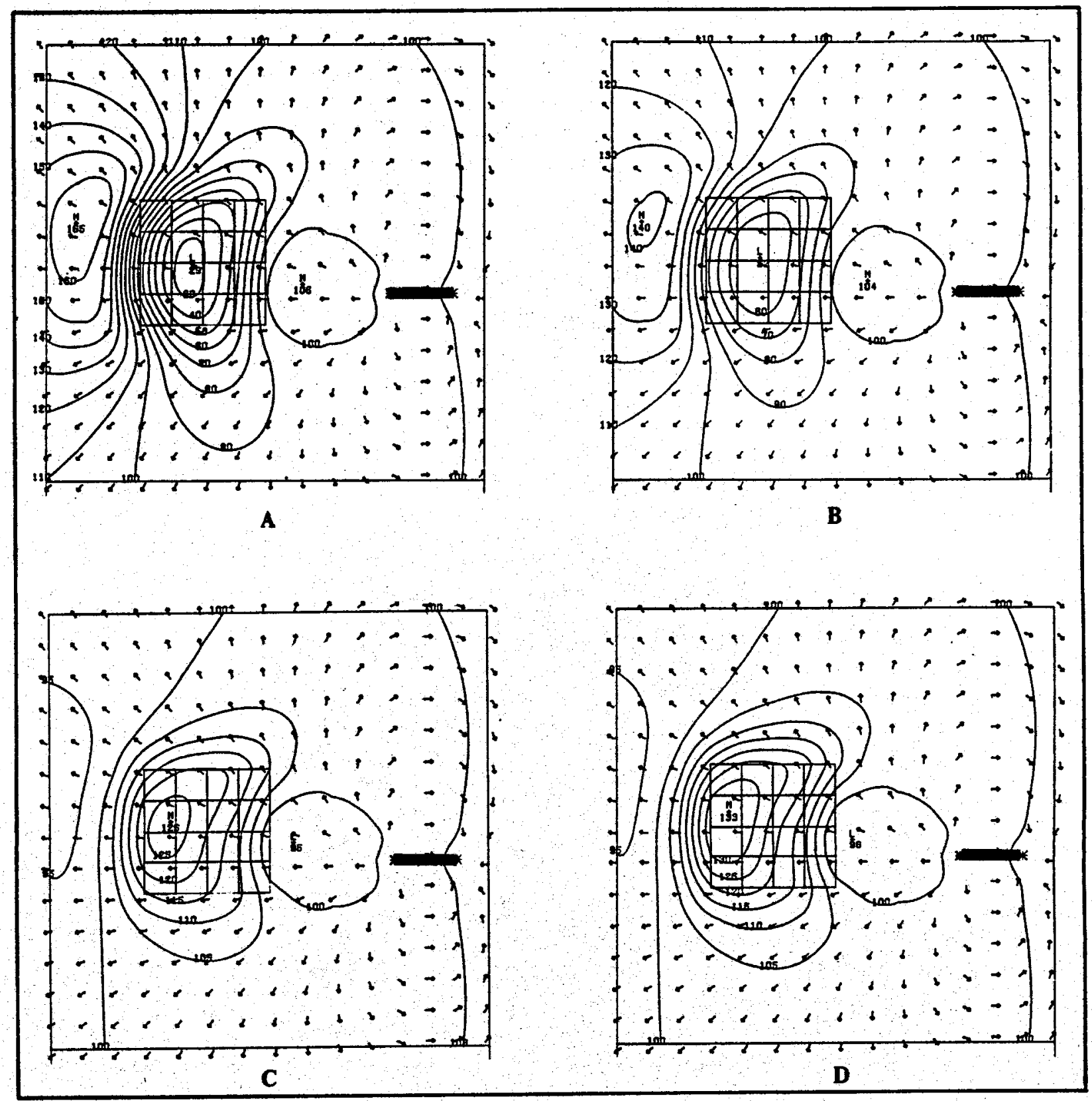

Figure 15. Effect of resistivity contrast - square body: $W=4, L=4, D E=1, D=1$, $\rho_{1}=100 ; A: \rho_{2}=1 ; B: \rho_{2}=10 ; C: \rho_{2}=10^{3} ; D: \rho_{2}=10^{4}$. 


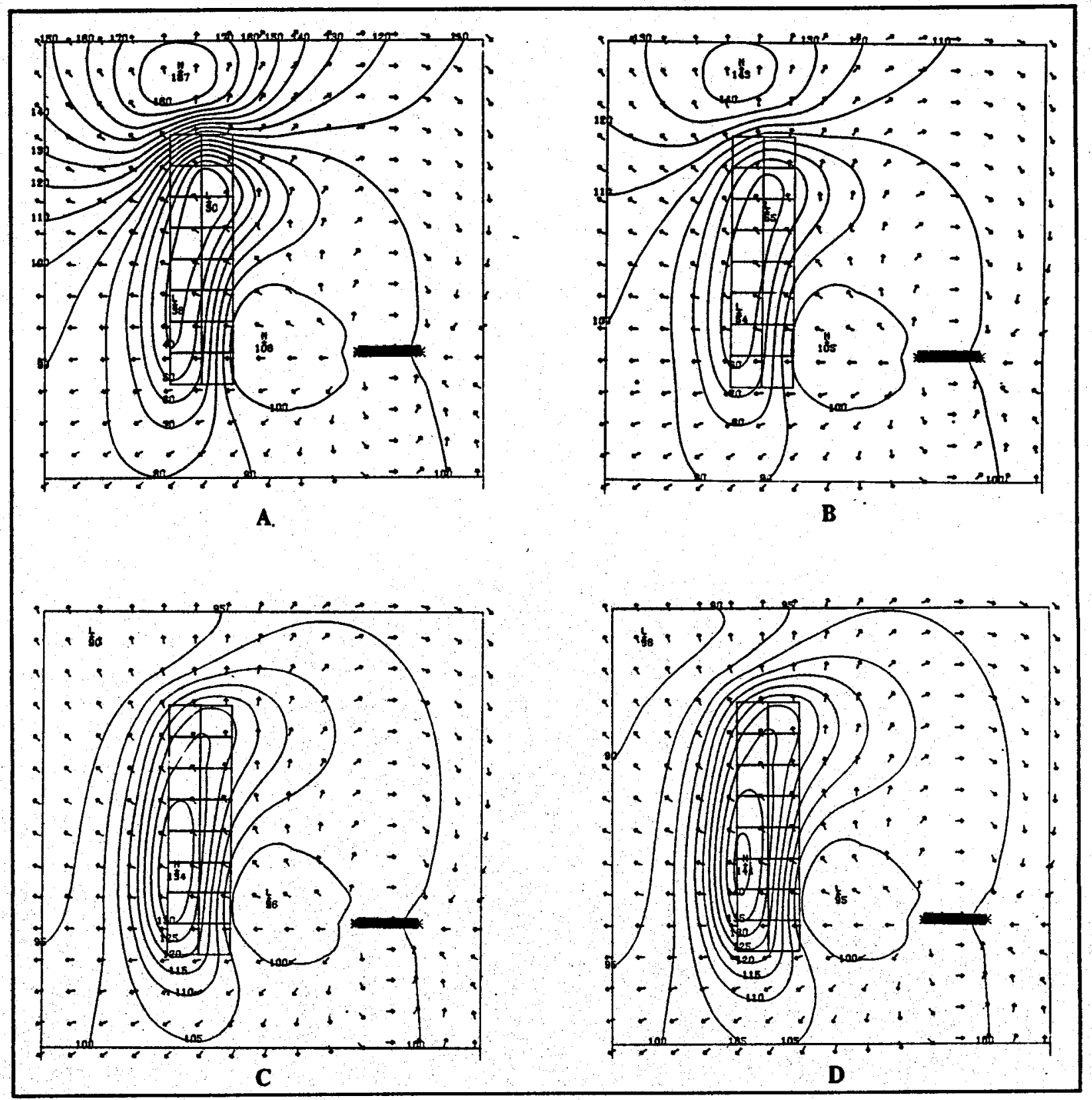

Figure 16. Effect of resistivity contrast - rectangular body: $W=2, L=8, D E=2$, $D=1, \rho_{1}=100 ; A: \rho_{2}=1 ; B: \rho_{2}=10 ; C: \rho_{2}=10^{3} ; D: \rho_{2}=10^{4}$. 


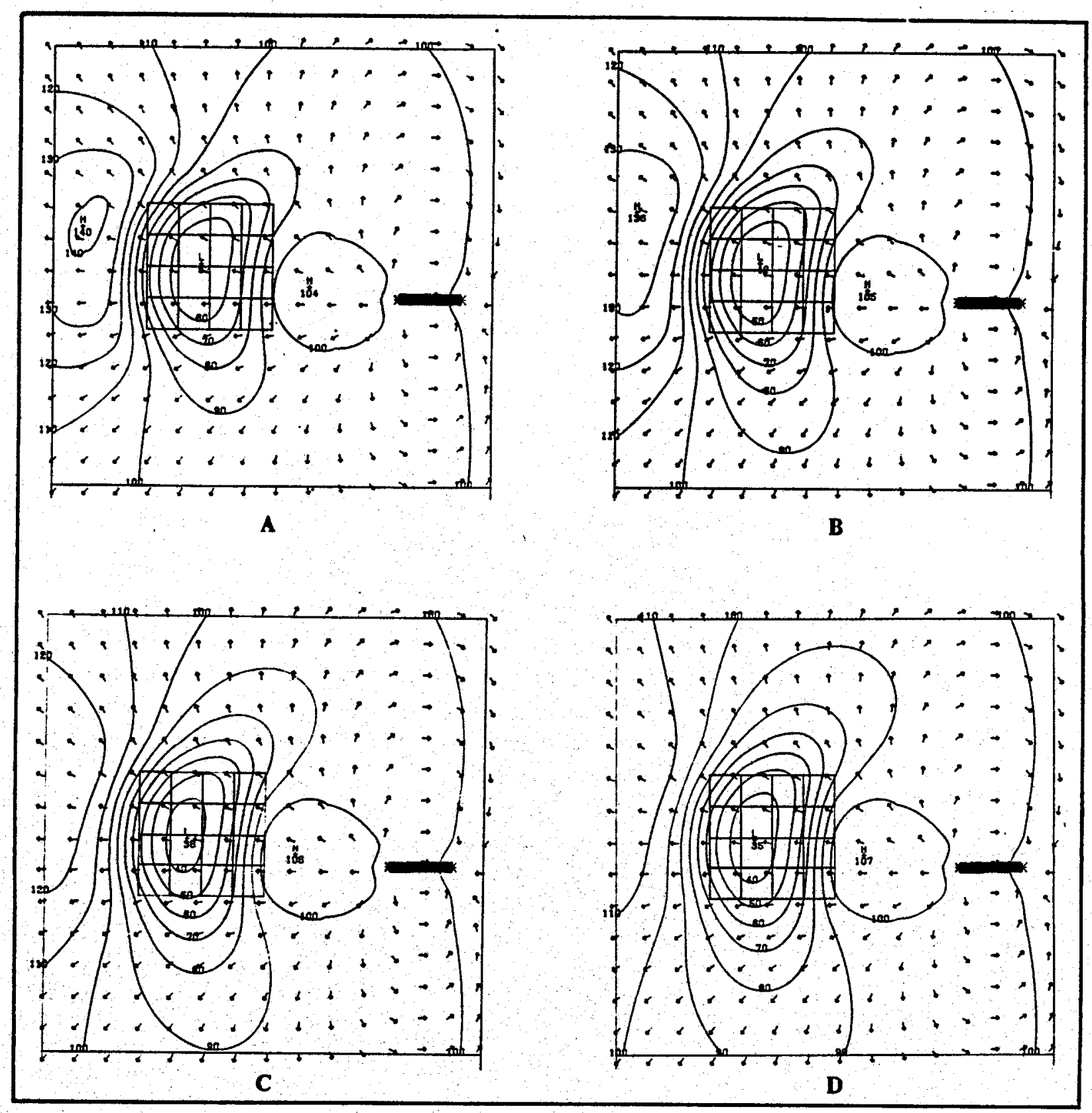

Figure 17. Effect of depth extent $(D E)$ - square body: $W=4, L=4, D=1, \rho_{2}=10$, $\rho_{1}=100 ; A: D E=1 ; B: D E=2 ; C: D E=3 ; D: D E=4$. 


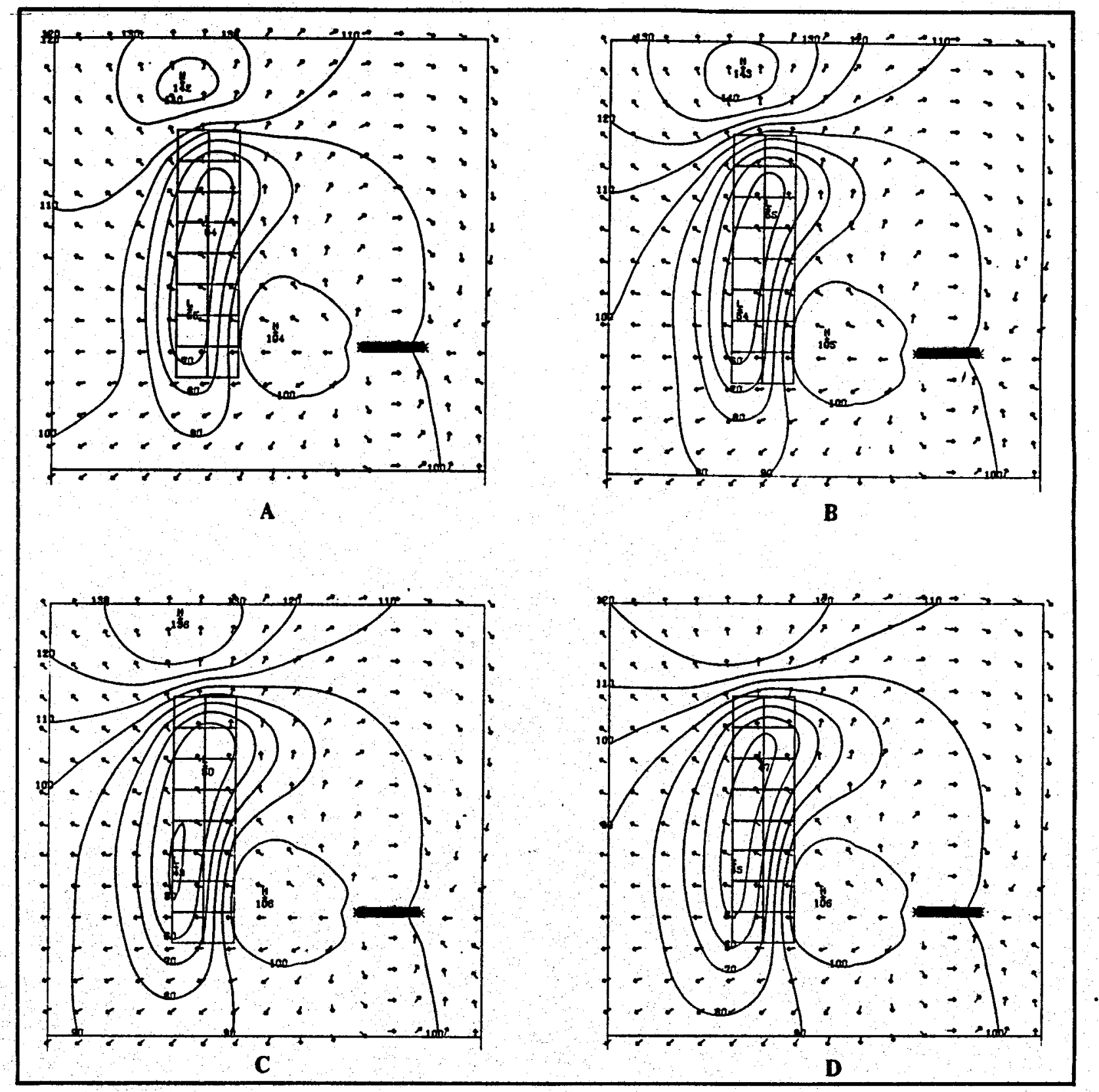

Figure 18. Effect of depth extent (DE)-- rectangular body: $W=2, L=8, D=1$, $\rho_{2}=10, \rho_{1}=100 ; A: D E=1 ; B: D E=2 ; C: D E=3 ; D: D E=4$. 


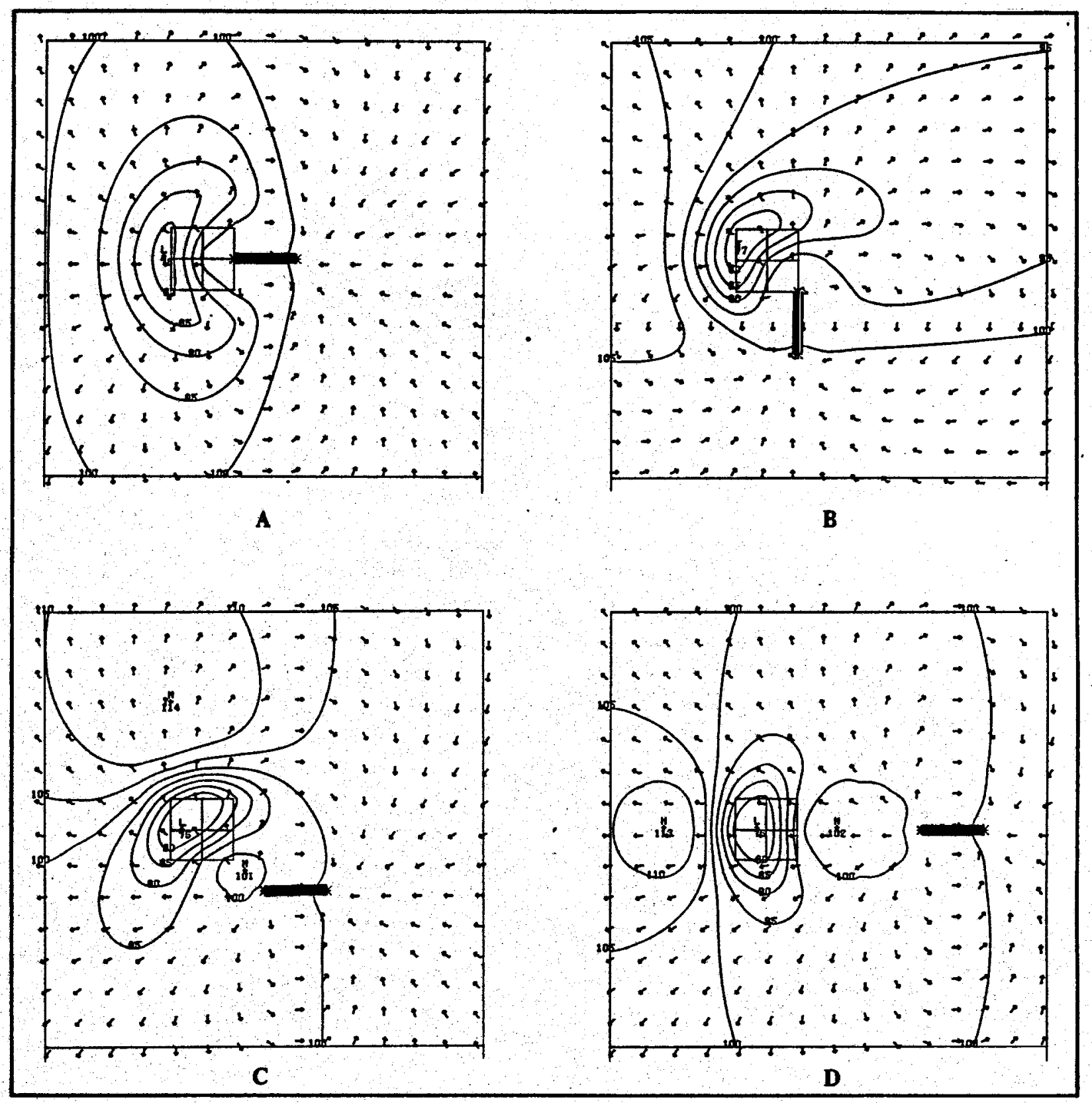

Figure 19. Bipole-dipole response of a small square body: $W=2, L=2, D E=2$, $D=1, p_{2}=10, p_{1}=100$. Compare with Figure 7 . 


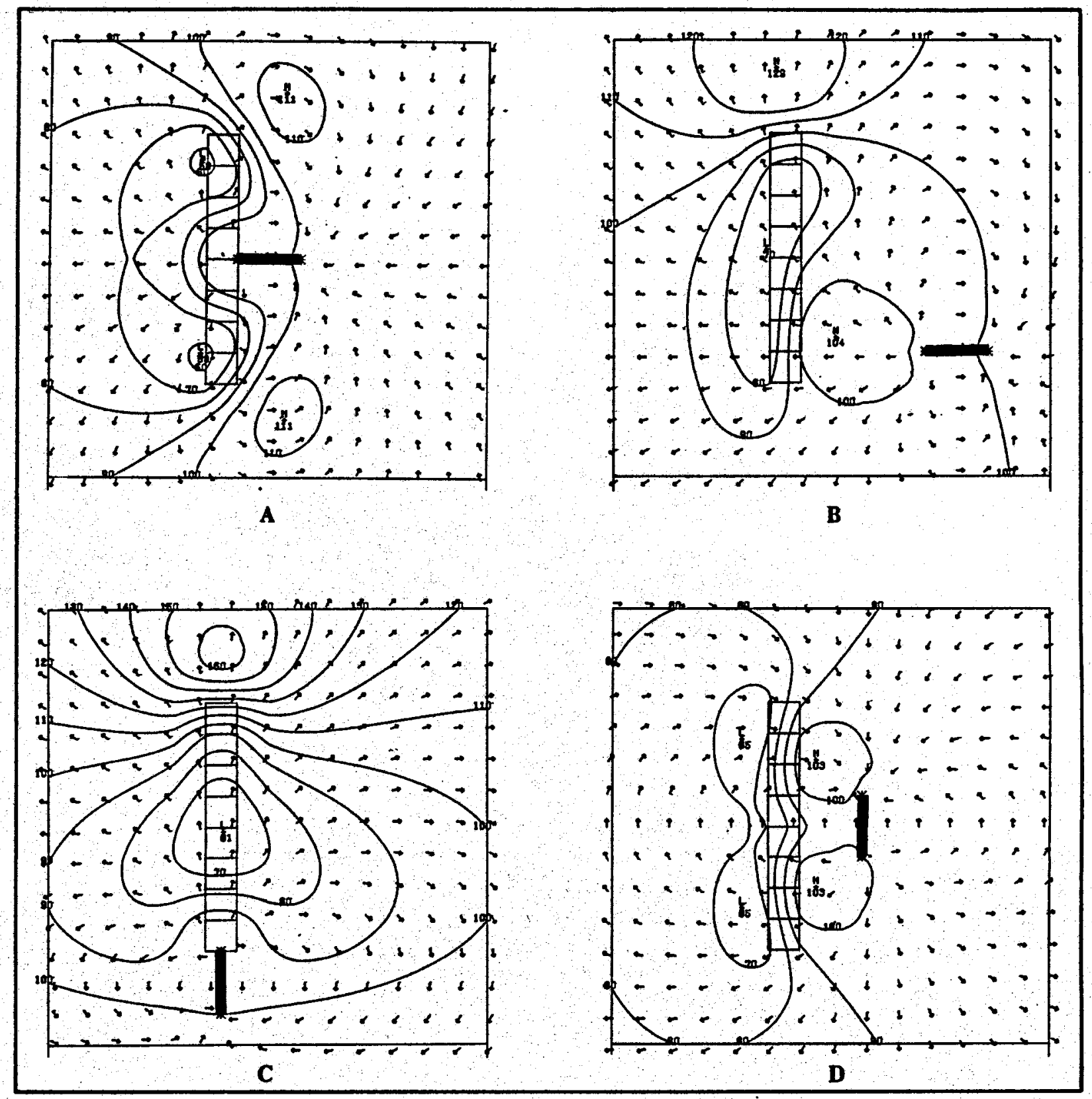

Figure 20. Bipole-dipole response of a long, narrow body: $W=1, L=8, D E=2$, $D=1, p_{2}=10, \rho_{1}=100$. Compare with Figures 10 and 11 . 


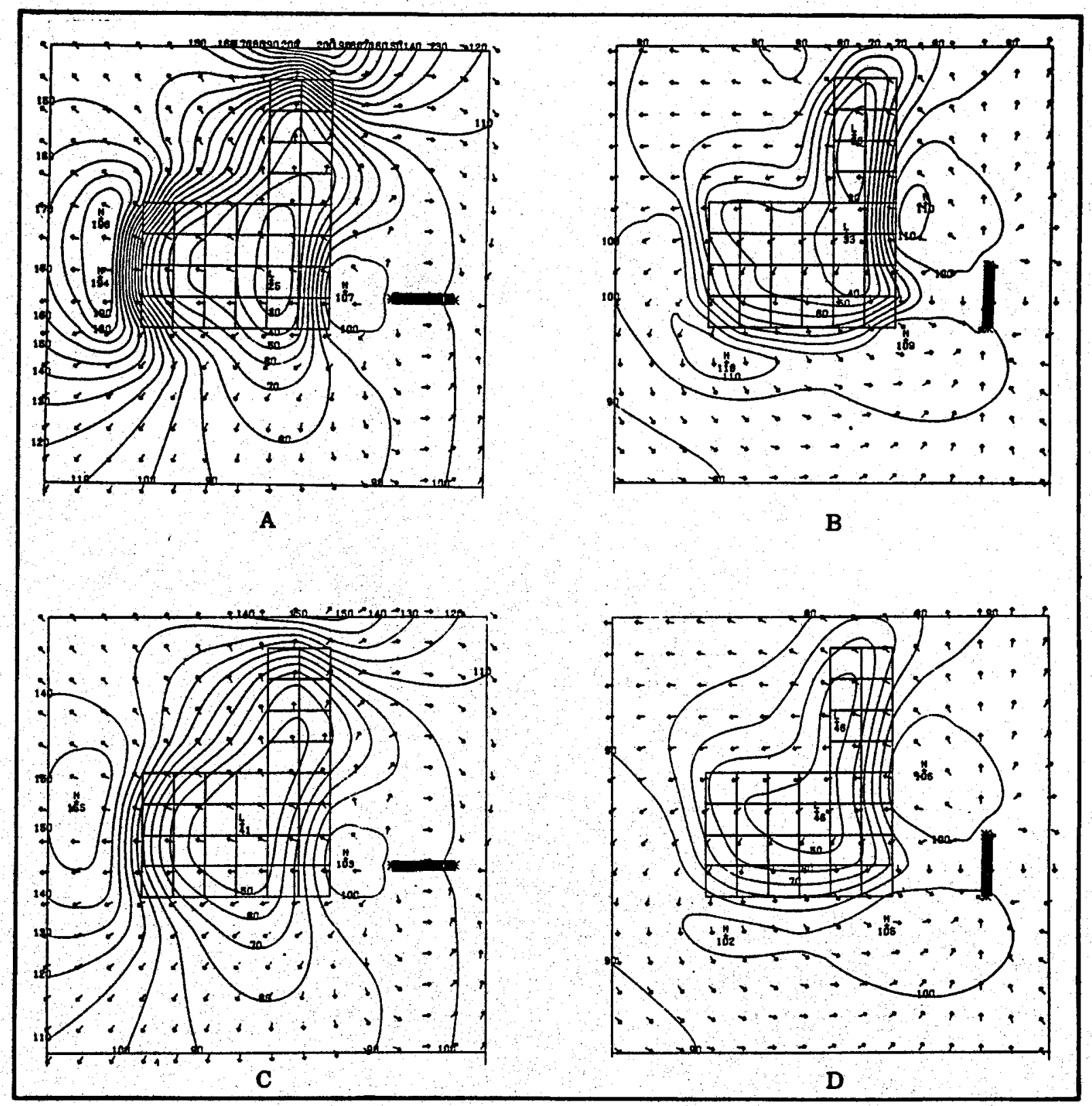

Figure 21. Bipole-dipole response of a complex conductive body. $A, B$ : depth= $0.5 ; C, D:$ depth $=1, p_{2}=10, p_{1}=100$. 


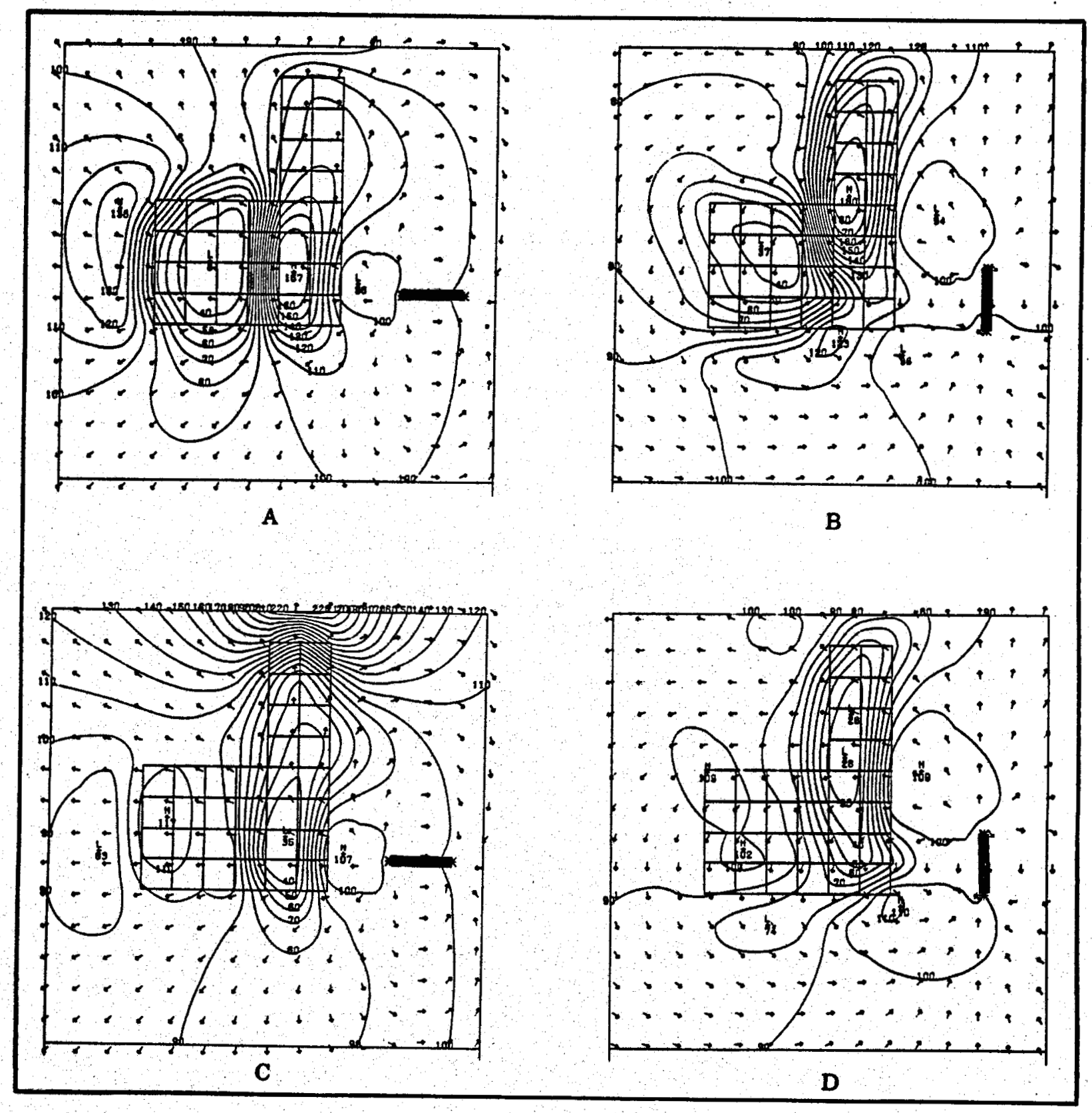

Figure 22. Bipole-dipole response of a complex body. $(D=0.5), A_{1} B$ : square body conductive $(\rho=10)$ - rectangular body resistive $\left(\rho=10^{3}\right) ; C, D$ : square body resistive $\left(\rho=10^{3}\right)$ - rectangular body conductive $(\rho=10)$. 


\section{C}

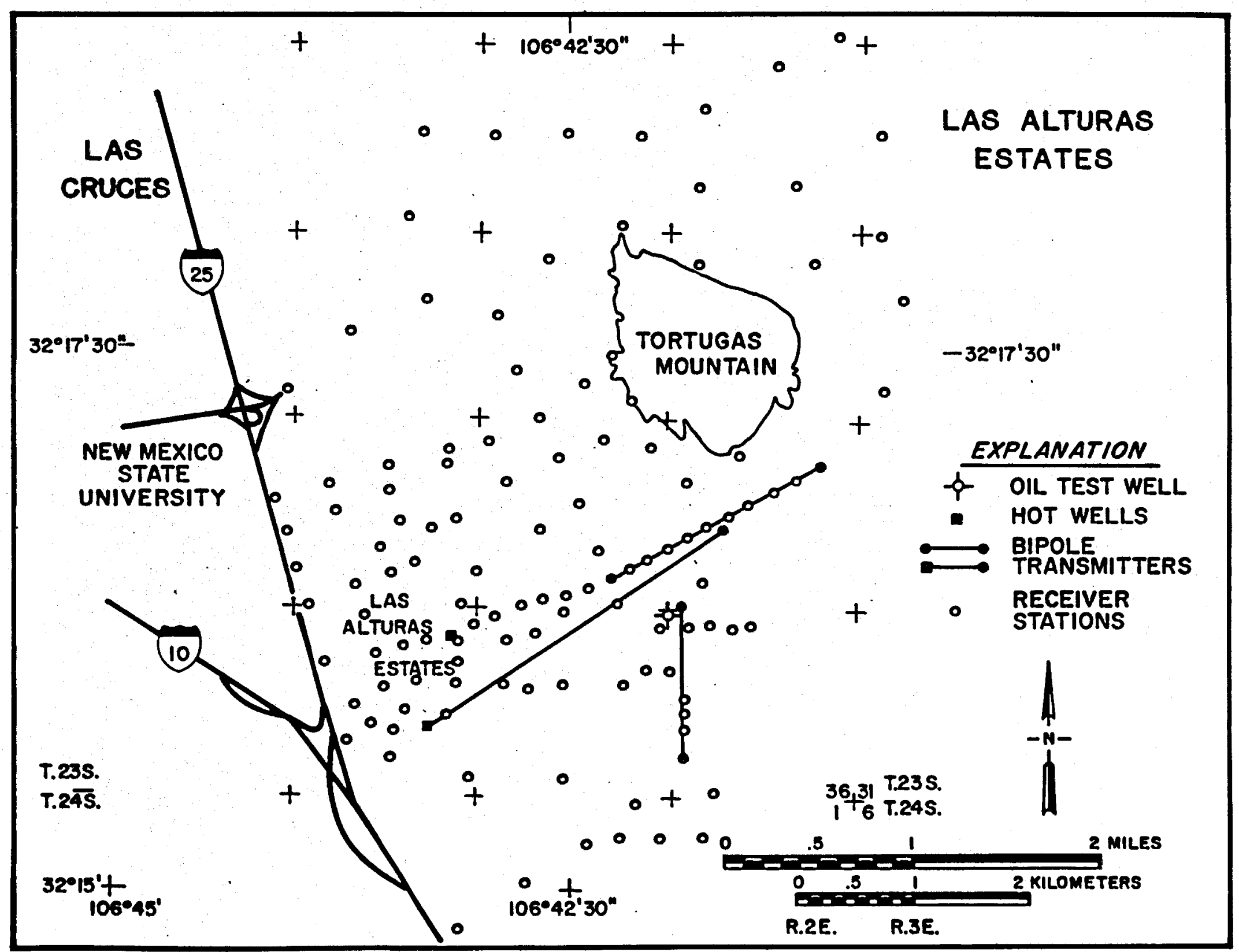

Figure 23. Map of Las Alturas Estates geothermal prospect. 


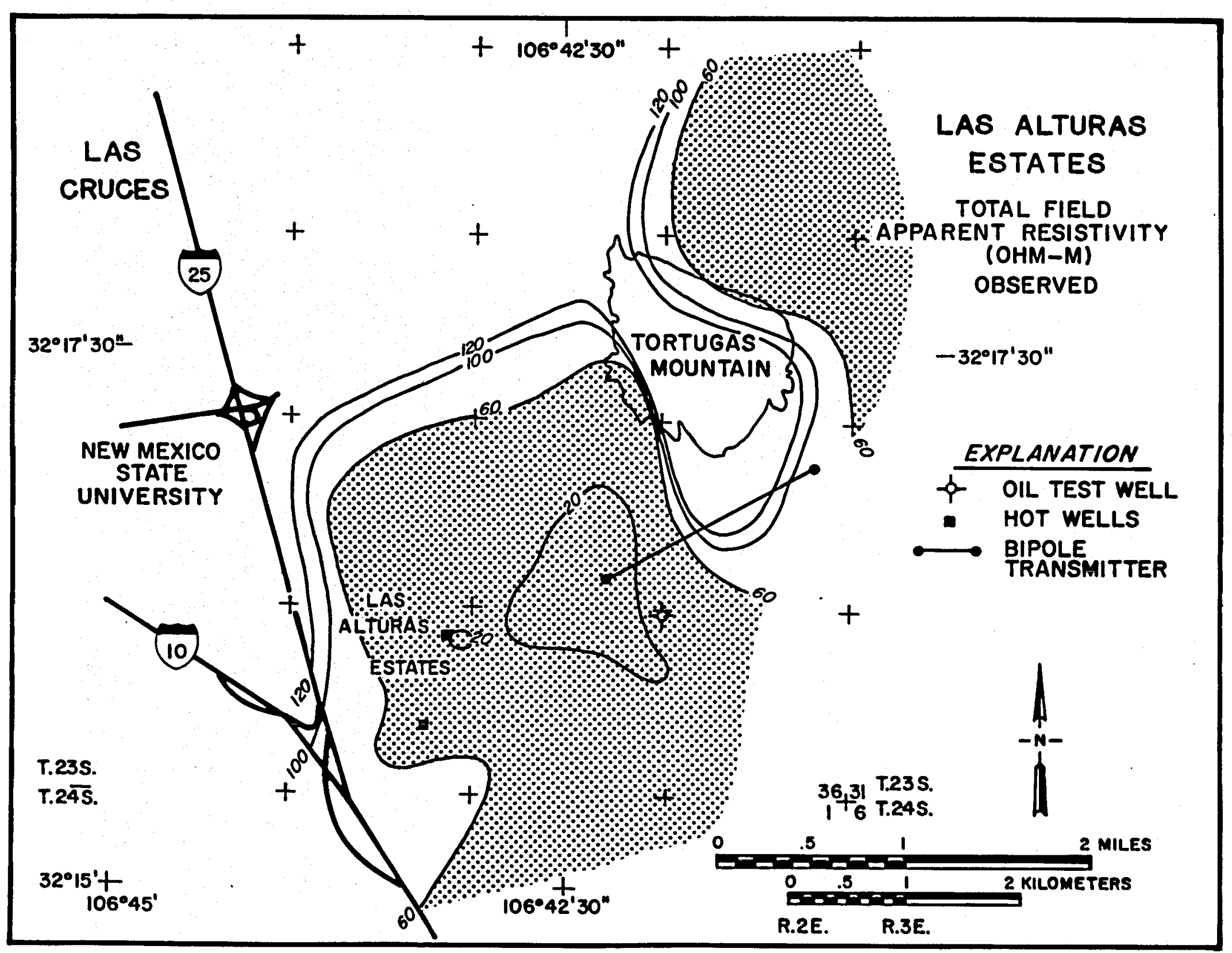

Figure 24. Bipole-dipole apparent resistivity map; one transmitter electrode over and one transmitter electrode outside conductive zone. 


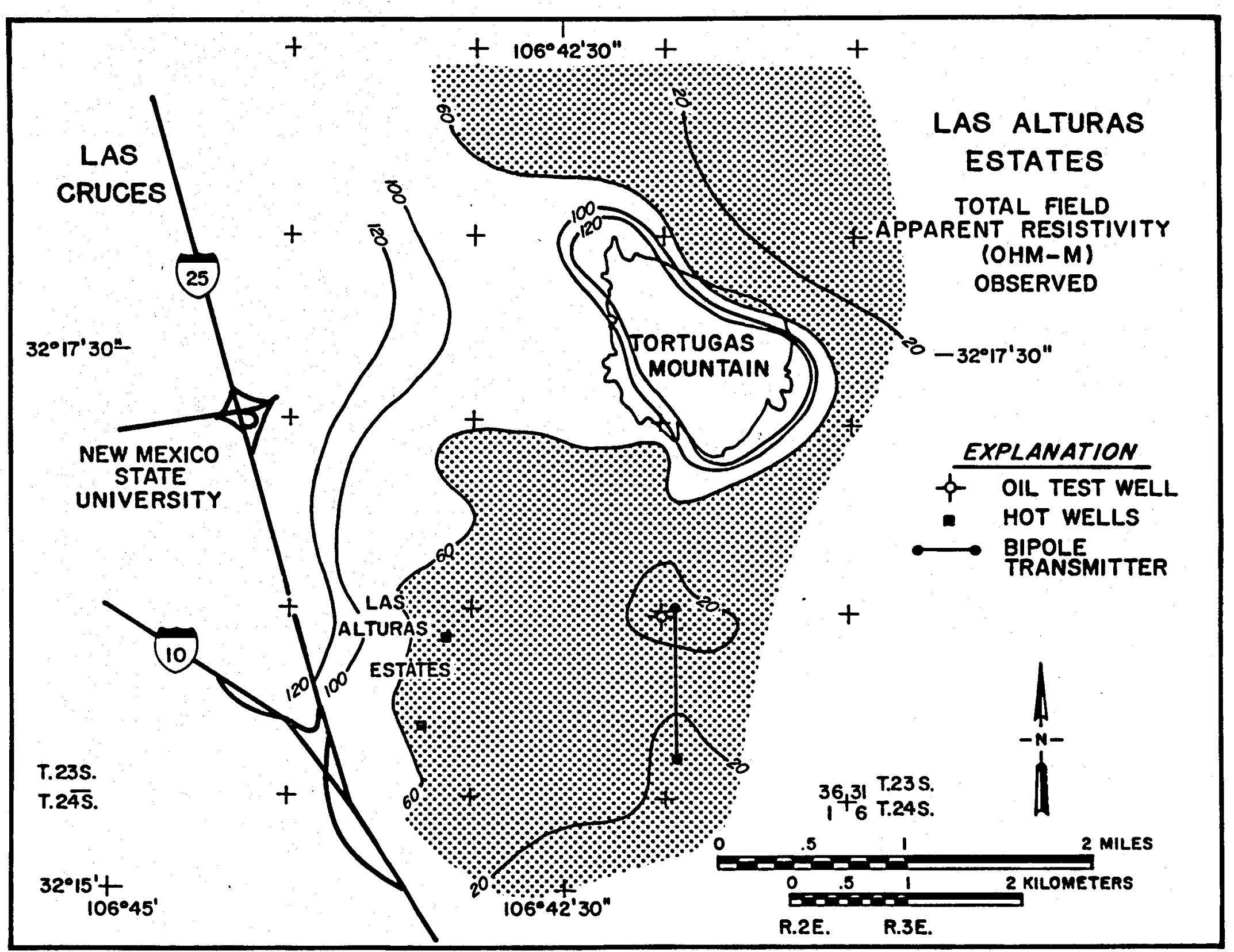

Figure 25. Bipole-dipole apparent resistivity map; both transmitter electrodes over conductive zone. 


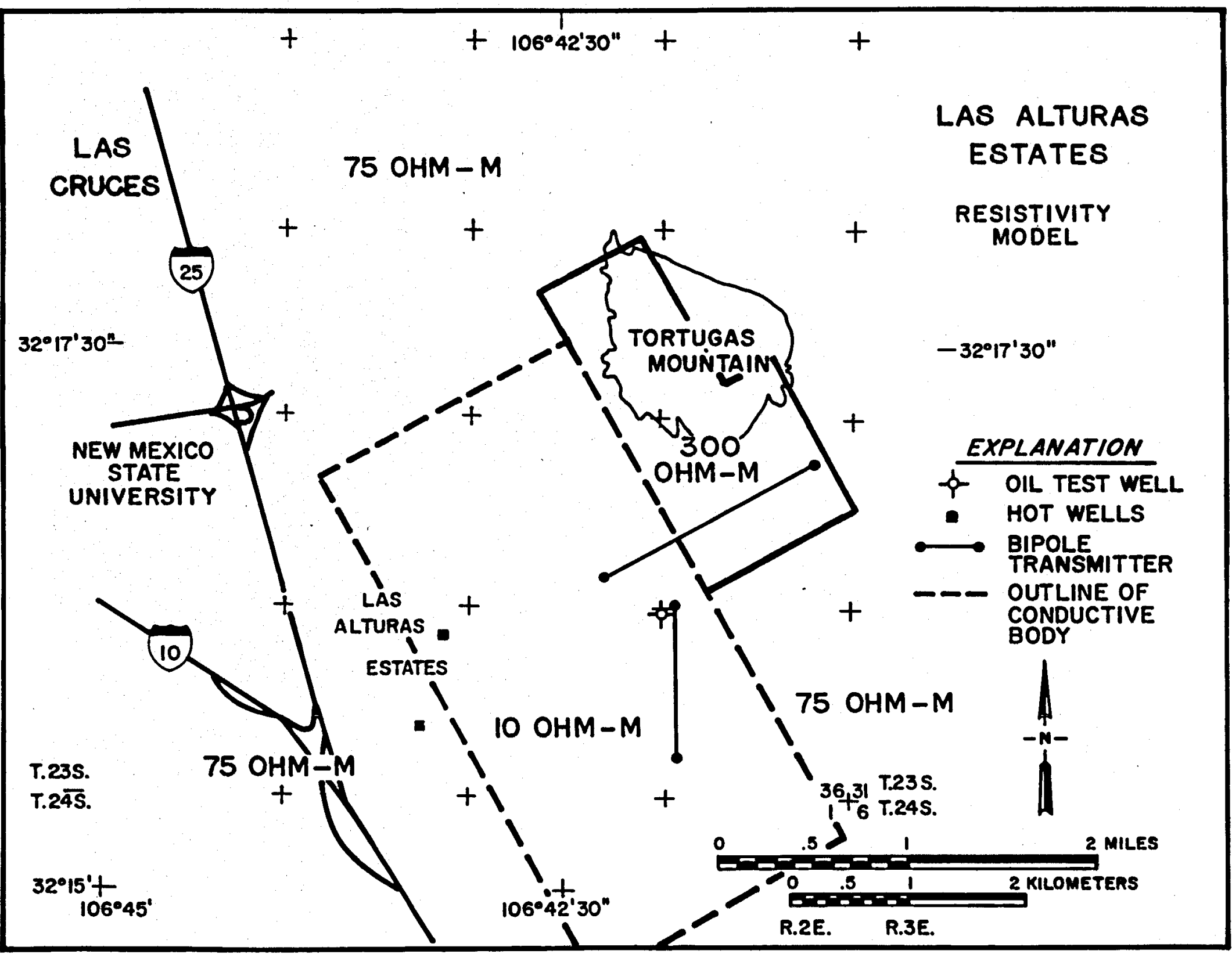

Figure 26. Three-dimensional interpretation model. 


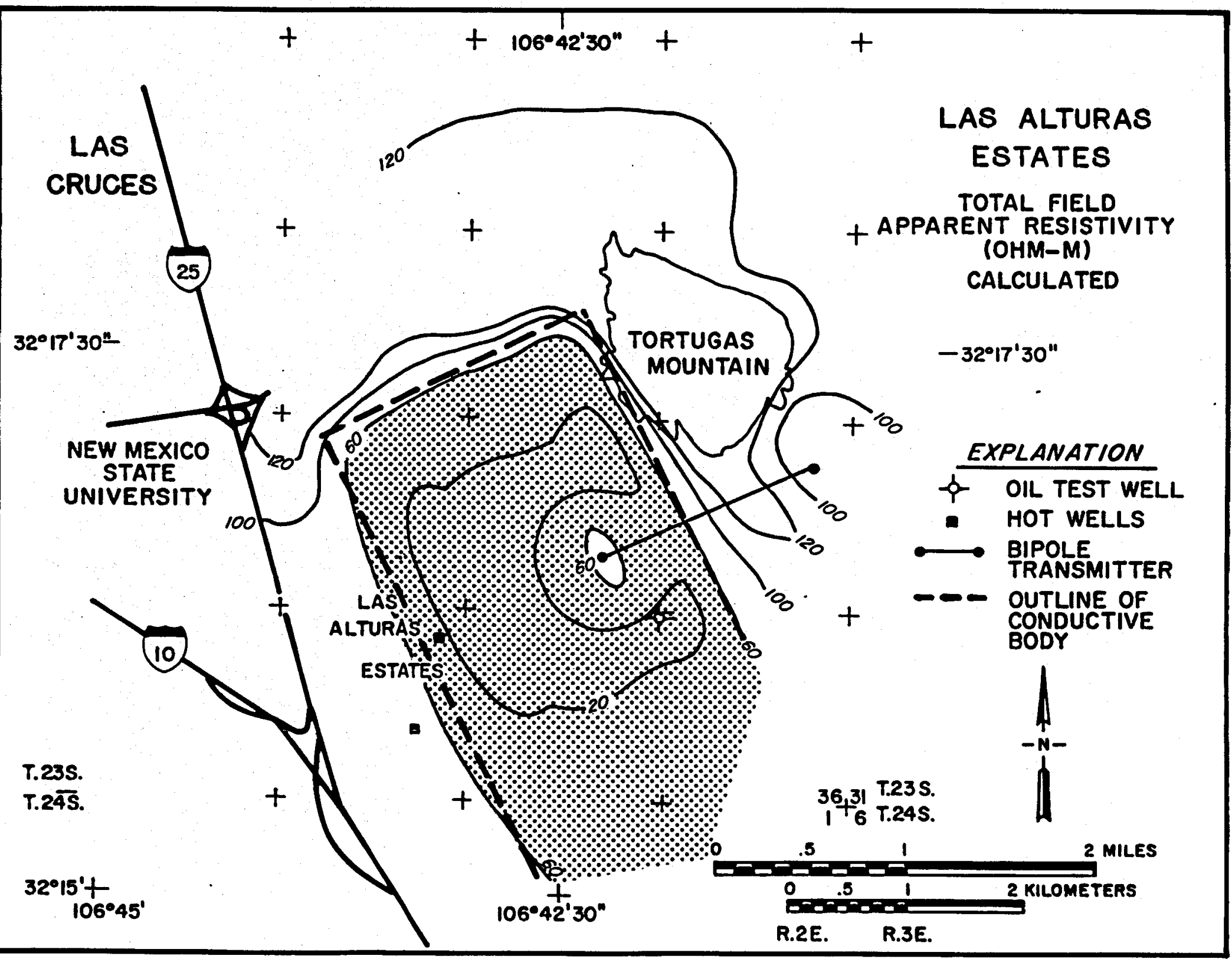

Figure 27. Theoretical results for the bipole of Figure 24. 


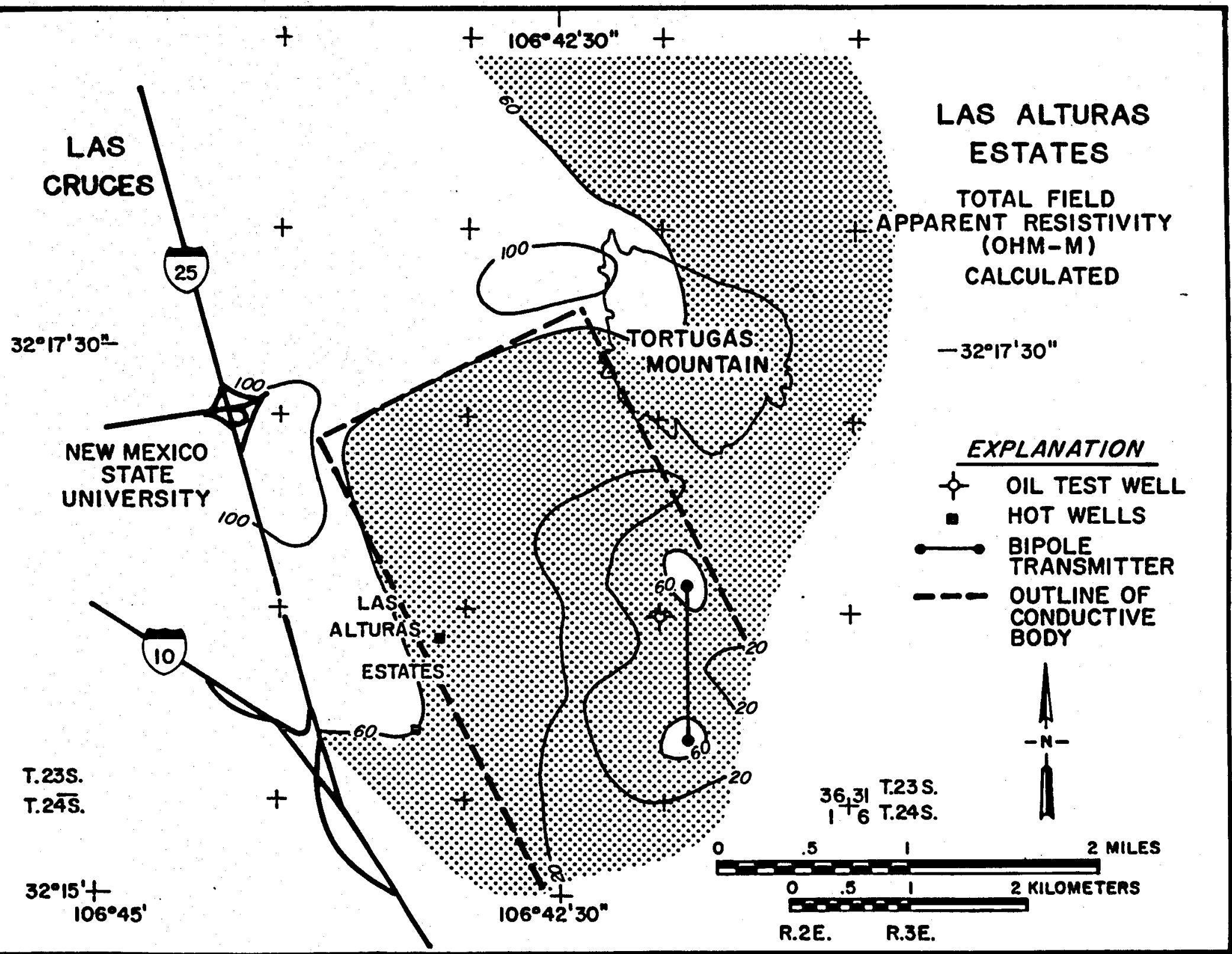

Figure 28. Theoretical results for the bipole of Figure 25. 


\section{DISTRIBUTION LIST}

External

David N. Anderson

James K. Applegate

Carl F. Austin

Lawrence Axtell

Larry Ball

Ronald Barr

R. Batra

Paul Baumgartner

H.C. Bemis

Harry Beyer

B. Bhattachryya

Sv. Bjornsson

David D. Blackwell

Gunnar Bodvarsson

C.M. Bonar

David Boore

G. Martin Booth

W. Clifford Bourland

Francis Bostick

Roger L. Bowers

P. M. D. Bradshaw

A.J. Brinker

Gerald Brophy

Will lam D. Brumbaugh

Larry Burdge

David Butler

David Butler

Glen Campbel1

Tom Campbel1

Philip R. Chandler

Ray Chantler

David S. Chapman

Roger Chapman

L. Chaturvedi

H.T. Chiu

Bob Christiansen

Jim Combs

F. Dale Corman

Ritchie Coryell

R. Corwin

John K. Costain

James Cotter

R.A. Crewdson
Geothermal Resources Counci1, Davis, CA.

Boise State University, Boise, ID.

Geothermal Technology, NWC, China Lake, CA.

Axtell Resources, Inc., Sol ano Beach, CA.

DOE-URE, Grand Junction, $\mathrm{CO}$.

Earth Power Corporation, Tulsa, OK.

Consuitant, Westminster, CO.

Exxon Minerals Co. USA, Denver, Co.

Fluid Energy Corporation, Denver, CO.

Consultant, El Cerrito, CA.

Indian School of Mines, Chanbad, India

Science Institute, Univ. Iceland, Reykjavik, Iceland

Southern Methodist University, Dallas, TX.

Oregon State University, Corvallis, $O R$.

Atlantic Richfield, Co., Dallas, TX.

Stanford University, Stanford, CA.

Geothermal Development Associates, Reno, NV.

Phillips Petroleum Co., Bartlesvilie, OK.

University of Texas, Austin, TX.

Hunt Energy Corporation, Dallas, TX.

Barringer Research, Rexdale, Canada

AT-Aquitaine Exploration, Ltd., Denver, CO.

DOE/DGE, Washington, DC.

Conoco, Ponca City, OK.

EG\&G Idaho, Idaho Falls, ID.

Micro Geophysics Inc., Golden, CO.

Chevron ofi Co., San Francisco, CO.

Gulf Min. Resource Company, Denver, Co.

Republic Geothermal, Inc., Santa Fe Springs, CA.

Geoscientific Systems \& Consulting, Playa del Rey, CA.

McCulloch Geothermal Corp., Los Angeles, CA.

University of Utah, Salt Lake City, UT.

California Division of Mines \& Geology, Sacramento, CA.

New Mexico State University, Las Cruces, NM.

Chinese Petroleum Corp., Miaoli, Taiwan, Republic of China

USGS, Menlo Park, CA.

Geothermal Services, Inc., San Diego, CA.

O'Brien Resources, Inc., Kentfield, CA.

National Science Foundation, Washington, DC.

University of California, Berkeley, CA.

Virginia Polytechnic Institute, Blacksburg, VA.

DOE/NV, Las Vegas, NV.

Occidental Geothermal, Bakersfield, CA. 
Gary Crosby

K. R. Davis

Edward Decker

Will Iam Dolan

Richard F. Dondanville

Earth Sciences Division Library

Gordon Eaton

Hans A.K. Edelman

Robert C. Edmiston

Wilf Elders

M.C. Erskine, Jr.

A. J. Farstad

Robert B. Forbes

Robert T. Forest

Ken Fournier

Frank Frischknecht

F. P. Fritz

Robert Furgerson

Mario Martinez $G$.

N.E. Goldstein

Sidney Green

Bob Greider

John Griffith

D.L. Gustafson

J.H. Hafenbrack

W.R. Hahman

Dee C. Hansen

$\checkmark$. Noble Harbinson

Norman Harthill

Asahi Hattori

Charles E. Helsley

John F. Hermance

Margaret E. Hinkle

W.A. Hirai

Donald B. Hoover

George Hopkins

Alan Q. Howard

S. Morris Hubbard

Don Hull

Gerald W. Huttrer

William F. Isherwood

Dallas Jackson.

Jimmy J. Jacobson

George R. Jiracek

Richard L. Jodry

Paul Kasameyer

Lewis $\mathrm{J}$. Katz.
Phillips Petroleum Company, Del Mar, CA.

Thermal Power Company, San Francisco, CA.

University of Hyoming, Laramie, WY.

Amax Exploration Inc., Denver, Co.

Union ofl Co., Santa Rósa, CA.

Lawrence Berkeley Laboratory, Berkeley, CA.

USGS, Hawail National Park, HI.

Prakla-Seismos GMBH, Hannover, Germany

Anadarko Production Co., Houston, TX.

University of California, Riverside, CA.

Eureka Resource Associates, Berkeley, CA.

Westinghouse Georesearch, Boulder, CO.

Alaska Geological \& Geophysical Consultants, Lopez, WA.

Phillips Petroleum Company, Reno, NV.

Union Research Center, Brea, CA.

U.S. Geological Survey, Denver, CO.

Fritz Geophysics, Golden, $\mathrm{CO}$.

Argonaut Enterprises, Denver, $\mathrm{CO}$.

Centro de Investigacion Cientifica Y Educacion

Superior de Ensenada, Ensenada, BC.

Lawrence Berkeley Laboratory, Berkeley, CA.

Terra Tek, Salt Lake City, UT.

Intercontinental Energy Co., Denver, CO.

DOE/ID, Idaho Falls, ID.

Homestake Mining Co., Reno, NV.

Exxon Co. USA, Denver, CO.

Arizona Bureau of Geology \& Mineral Technology, Tucson, $A Z$.

Utah State Engineer, Salt Lake City, UT.

O'Brien Resources, Incorporated, Toronto,

Ontario, Canada.

Group Seven, Incorporated, Golden, CO.

Bishimetal Exploration Co., Tokyo, Japan

Hawail Institute of Geophysics, Honolulu, HI.

Brown University, Providence, RI.

USGS-Exploration Research, Golden, CO.

W.A. Hirai \& Associates, Hilo, HI.

USGS, Golden, CO.

Geotronics Corp., Austin, TX.

University of Arizona, Tucson, AZ.

Denison Mines Inc., Spokane, WA.

Oregon Dept. of Geology \& Mineral Industries,

Portland, $\mathrm{OR}$.

Intercontinental Energy Corporation,

Englewood, $\mathrm{CO}$.

USGS, Mento Park, CA.

USGS, HIlo, HI.

Battelle Pacific Northwest Labs., Richland, WA.

University of New Mexico, Albuquerque, NM.

Richardson, TX.

Lawrence Livermore Laboratory, Livermore, CA.

Utah Geophysical, Incorporated, Salt Lake City, UT. 
George Keller

B. Khel if

Paul Kintzinger

James B. Koenig

Roger Kolvoord

Mark Landisman

Art Lange

D. Larsen

A.W. Laught in

T. J. Lee

R.C. Lenzer

Library

Paul Lienau

Jack J. Loo

Don R. Mabey

Ted Madden

Maurice Magee

Larry 0. Mann

Mark Mathews

Skip Matlick

M.D. Mattice

Al do Mazella

Robert B. McEuen

Don C. McMillan

J.R. McNitt

Tsvi Meidav

Jim Mercer

Frank G. Metcalfe

John Mitchell

Paul Morgan

Frank Morrison

L.J. Patrick Muffler

Misac Nabighian

Clayton Nichols

Denis Norton

D. P. O'Brien

Gary 01 hoeft

Carel otte

G. Palmason

Richard H. Pearl

Wayne Peeples

Roger Phillips

Don Pridmore

Robert 0. Prindle

Vincent Radja

Alan 0. Ramo

Marshall Reiter

Marshall Reed

Robert W. Rex

William L. Rodi
Colorado School of Mines, Golden, Co.

Ministry of Power, Algiers, Algeria

Los Alamos Scientific Laboratory, Jemez

Springs, NM.

Geothermex, Berkeley, CA.

Diversified Exploration Services, Lewisville, TX.

University of Texas, Dallas, Richardson, TX.

AMAX Exploration, Incorporated, Denver, CO.

Consultant, Washington, $D C$.

Los Alamos Scientific Laboratory, Los Alamos, NM.

L.A. Richardson \& Associates, Pty, Gordon, Australia

Phillips Petroleum Company, Del Mar, CA.

New Mexico Energy Institute, Las Cruces, NM.

OIT, Klamath Falis, OR.

Dept. of Navy, San Bruno, CA.

USGS, Salt Lake City, UT.

M.I.T., Cambridge, MA.

Jack C. Webster, Inc., Salt Lake City, UT.

U.S. DOE, Seattle, WA.

LASL, Los Alamos, NM.

Repubilic Geothermal, Santa Fe Springs, CA.

Hawali Institute of Geophysics, Honoluiu, HI.

Terra Physics, Richmond, CA.

Woodward Clyde Consultants, San Francisco, CA.

Utah Geological \& Mineral Survey, Salt Lake City, UT.

Energy and Mineral Development Branch, United

Nations, NY.

Consultant, Berkeley, CA.

USGS, Reston, VA.

Geothermal Power Corporation, Novato, CA.

Idaho Dept. of Water Resources, Boise, ID.

New Mexico State University, Las Cruces, NM.

University of California, Berkeley, CA.

USGS, Menlo Park, CA.

Newmont Mining Co., Tucson, AZ.

DOE-Idaho Operations Office, Idaho Falls, ID.

University of Arizona, Tucson, AZ.

QEB, Hayward, CA.

USGS, Denver, CO.

Union 011 Company, Los Angeles, CA.

Orkustofnun, Reykjavik, I celand

Colorado Geological Survey, Denver, Co.

Southern Methodist University, Dalias, TX.

Jet Propulsion Lab., Pasadena, CA.

Western Mining Corp., Kalgoorile, Australia

Eureka Resource Associates, Inc., Berkeley, CA.

Indonesian State Electric Co., Bandung, Indonesia

Sunoco Energy Development Company, Dalias, TX.

New Mexico Institute of Mining \& Technology,

Socorro, NM.

USGS, Menio Park, CA.

Republic Geothermal, Inc., Santa Fe Springs, CA. Systems, Science and Software, Inc., LaJolla, CA. 
Jack Salisbury

S.K. Sanyal

Konosuke Sato

C.E. Schubert

Wayne Shaw

S. Shikinami

R.C. Shopland

Donald W. Smellie

H.W. Smith

Donald D. Snyder

John Sonderegger

Jose Souto

W. D. Staniey

Neil Stefanides

Ben Sternberg

Robert Sultzbach

John S. Sumner

Chandler Swanberg

Charles M. Swift, Jr.

Robert L. Tabbert

Ronald Toms

Dennis $T$. Trexler

John Tsiaperas

Donald $L$. Turner.

U.S.G.S. Libraries

Gerald Van Voorhis

James R. Wait

D. Roger Wall

Ronald W. Ward

Jack Webster

Gordon West

Western Mining Corp.

J.H. Wherry

Gordon Wieduwilt

Paul Witherspoon

Dick Wood

B.J. Wynat

Walter Youngquist

S.H. Yungul

K. Zonge

Ernst G. Zurflueh

Internal

S.H. Ward (2)

P.M. Wright

W. Ursenbach

H.P. Ross

W. R. St11

C. Smith

W.E. Glenn

T.J. Killpack

Master Report File
DOE/DGE, Washington, DC.

Stanford University, Stanford, CA.

Metal Mining Agency of Japan, Minato-Ku, Tokyo.

D'Appolonia, Pittsburgh, PA.

Getty 011 Company, Bakersfield, CA.

Consultant, Tokyo, Japan

Western Geophysical Co., Houston, TX.

Gulf Minerals Canada Ltd., Toronto, Canada

University of Texas, Austin, TX.

EDCON, Denver, CO.

Montana Bureau of Mines \& Geology, Butte, MT.

Colorado School of Mines, Golden, CO.

USGS, Denver, CO.

Union 011 Company, Los Angeles, CA.

Conoco, Ponca City, OK.

Exxon Minerals Co. USA, Denver, Co.

University of Arizona, Tucson, AZ.

New Mexico State University, Las Cruces, NM.

Chevron oil Company, San Francisco, CA.

Atlantic Richfield Company, Dallas, TX.

DOE/DGE, Washington, DC.

Nevada Bureau of Mines \& Geology, Reno, NY.

Shell oil Company, Houston, TX.

University of Alaska, Fairbanks, AK.

Reston, VA.

Denver, CO.

Menlo Park, CA.

Bear Creek Mining Co., Tucson, AZ.

NOAA Environmental Research Lab., Boulder, CO.

Aminoll USA, Inc., Santa Rosa, CA.

University of Texas, Dallas, Richardson, TX.

Scintrex Mineral Surveys, Salt Lake City, UT.

University of Toronto, Toronto, Canada.

Kalgoorlie, Australia

Author, Puyallup, WA.

Mining Geophysical Surveys, Tucson, AZ.

Lawrence Berkeley Laboratory, Berkeley, CA.

DOE/DGE, Idaho Falls, ID.

Occidental Geothermal, Inc., Bakersfield, CA.

Consul tant, Eugene, $O R$.

Chevron Resources Company, San Francisco, CA.

Zonge Engineering \& Research, Tucson, AZ.

International Energy Co., San Francisco, CA.

UU/GG, Salt Lake City, UT.

ESL/UURI, Salt Lake City, UT.

UURI, Sait Lake City, UT.

ESL/UURI, Salt Lake City, UT.

UU/GG, Salt Lake City, UT.

ESL/UURI, Salt Lake City, UT.

ESL/UURI, Salt Lake City, UT.

ESL/UURI, Salt Lake City, UT.

ESL/UURI, Salt Lake City, UT. 